\title{
INVESTIGATING THE ALLELIC VARIATION OF LOCI CONTROLLING RUST RESISTANCE GENES IN WHEAT (Triticum aestivum L.) LAND RACES BY SSR MARKER
}

\author{
KHATTAK, S. H. $.^{1,2^{*}}-$ BEGUM, S. $^{2}-$ AQEeL, M. $^{2}-$ FAYYAZ, M. ${ }^{3}-$ BANGASH, S. A. K. ${ }^{4}-$ \\ RIAZ, M. N. ${ }^{2}-$ SAEED, S. ${ }^{5}-$ AHMED, A. ${ }^{5}-$ ALI, G. M..$^{2 *}$ \\ ${ }^{1}$ Quaid-i-Azam University, Islamabad, Pakistan \\ ${ }^{2}$ National Institute for Genomics \& Advanced Biotechnology, National Agricultural Research \\ Centre, Islamabad 45500, Pakistan \\ ${ }^{3}$ Crop Disease Research Institute (CDRI), Plant and Environmental Department, National \\ Agricultural Research Centre, Islamabad 45500, Pakistan \\ ${ }^{4}$ Institute of Biotechnology and Genetic engineering (IBGE), The University of Agriculture, \\ Peshawar, Pakistan \\ ${ }^{5}$ Department of Botany, University of Balochistan, Quetta, Pakistan \\ *Corresponding authors \\ e-mail: sahir_999@hotmail.com (phone: +92-331-9201-636); drgmali5@gmail.com
}

(Received $6^{\text {th }}$ Jul 2020; accepted $17^{\text {th }}$ Sep 2020)

\begin{abstract}
A study was conducted to determine the status of gene combination for rust (Puccinia spp.) resistance in 100 indigenous wheat land races also yield related traits were evaluated at two different locations during the 2016-17 periods with Randomized Complete Block Design. Variations for the studied traits were conferred by Principal Component Analysis (PCA), PC1 with $80.1 \%$ variation for the Peshawar, and $93.8 \%$ for the Islamabad location. WMC419, XGWM120, GWM174, XGWM140, XGWM410, XGWM111, WMC773, XWMC170, XWMC405, XWMC348 and XWMC407 has no allelic variation because of monomorphic nature while XGWM35 (200\&225 bp), GWM 148 (190\&200 bp), Barc 86 (200\&210 bp), BARC 114 (105\&200 bp), CSLV34 (150\&190 bp), PSP3000 (300\&350 bp), XGWM493 (150\&300 bp), XGWM153 (100\&300 bp), XGWM44 with 120,285,500 \& 700 bp, XBARC4 (90\&200 bp), XGWM125 (150\&190 bp) show variation in alleles. Analysis of Yellow rust (Yr5,7,10,15,18,19,26,29,34, P138 and Sr13,) and leaf rust (Lr19,34 and 49) revealed A and B resistance groups. Group A comprised of $36 \%$ of total accessions, while rest of the accessions (64\%) were present in group B. The study revealed high level of diversity assessed through PCA and cluster analysis. Based on marker results, 23 wheat lines ranging 17-21 alleles in combination were identified. These lines have great potential to be used in rust resistance breeding programs.
\end{abstract}

Keywords: indigenous germplasm, yield related traits, principal component analysis, cluster analysis

\section{Introduction}

Wheat (Triticum aestivum L.) is an essential cereal crop with a variety of uses and is considered the major component of bread. It belongs to the family Poaceae and genus Triticum and ranks first in cereals. It is a staple diet and provides more nourishment for the people of the world than any crop. There are two kinds of wheat species on which the world wheat production depends. The common/ bread wheat, which is mostly used today, has $42(42=2 \mathrm{n}=6 \mathrm{x})$ chromosomes containing AA, BB and DD genomes (Goutam et al., 2013). Wheat has high nutritional value and it gives nearly $21 \%$ of calories along with $20 \%$ of the protein (Waqar et al., 2018). During 
2018 it was grown on an 8.7 mha area with 250 million tones production (FAO, 2020). This yield is still not enough to meet global requirements and climatologists also predicted that if existing/available cultivars and agronomic practices are used there is high chance that nearly $30 \%$ yield reduction will occur in South Asia's zone (Cgiar, 2017). One of the main factor in decline of yield are wheat diseases particularly Rust which is a common name for Puccinia spps i.e. fungal pathogens affecting lots of cereal crops especially wheat (Brown and Hovmøller, 2002; Waqar et al., 2018). Rust disease slows the growth of plant and decrease forage quality, also it results in poor seedling germination, foliar damage and reduced grain size (Chen et al., 2012). Seriousness of this disease can be depicted by its ability to grow everywhere provided that suitable substrate that may be wheat or other species in favorable environmental conditions. It can also pose a high risk to a lot of sustainable wheat production zones (Singh et al., 2004). Pandemic of rusts disease caused for example the $19^{\text {th }}$ century famine that covered large area of the world and affected human. This famine nearly cost 5 billion US dollars losses to cereals especially wheat for many years (Waqar et al., 2018). The severity of the disease affects the yield attributing traits. Therefore, appropriate selection of rust resistance parents is important in crossing nurseries/programs to enhance the genetic recombination for capability of yield enhancement by reducing rust losses (Ajmal et al., 2013).

In Pakistan not much studies have been conducted in order to characterize rust resistant genes using DNA markers particularly SSR for developing rust resistant varieties through gene pyramiding. Developed varieties must be resistant and high yielding. This can be achieved by using the best available technique/designs like ANOVA, PCA, cluster analysis and other statistical tools. PCA is the best tool and is used worldwide for exploring similarities; dissimilarities along with hidden patterns between genotypes especially in land races or if the association on data and grouping is not very clear (Granato et al., 2018). Similarly for markers there are lots of categories but two main groups are broadly used i.e. PCR-based SSRs and AFLPS (Granato et al., 2020). Long term fertility building requires a combined methodology instead of short range approach and targeted way out instead of conventional agriculture approaches, therefore combined efforts of agriculture scientists (of diverse discipline) specially plant breeders and geneticist is required to overcome loss inflicted by lethal disease i.e. rust by incorporation of resistance alleles in various high yielding crops through breeding programs (Waqar et al., 2018). Considering the situation of our country this study was done to evaluate the rust resistance alleles/genes at various loci in indigenous Pakistani wheat germplasm and also to evaluate their performance across different yield related traits for their future incorporation in different breeding programs.

\section{Materials and Methods}

The breeding material was collected from BCI, National Agriculture Research Center (NARC) Islamabad, Pakistan (official germplasm of Pakistan). For experimental study and to screen huge breeding material, germination test (15 seeds accession ${ }^{-1}$ ) was performed at lab for the selection of 100 elite performer land races (out of 1000) using Filter paper Whatman No. 1 sheet (Punjabi and Basu, 1982). Accessions having higher germination rate i.e. above $70 \%$ were registered for further experimental analysis (Table 1). 
Table 1. Performance of 100 selected accessions on the basis of germination test

\begin{tabular}{|c|c|c|c|c|c|c|c|}
\hline $\begin{array}{c}\text { Accessions } \\
\text { name }\end{array}$ & $\begin{array}{c}\text { Accessions } \\
\text { coding }\end{array}$ & \begin{tabular}{|c|}
$\begin{array}{c}\text { Germinated } \\
\text { seed }\end{array}$ \\
\end{tabular} & $\begin{array}{c}\text { Germination } \\
\% \text { age }\end{array}$ & $\begin{array}{c}\text { Accessions } \\
\text { name }\end{array}$ & $\begin{array}{c}\text { Accessions } \\
\text { coding }\end{array}$ & \begin{tabular}{|c|}
$\begin{array}{c}\text { Germinated } \\
\text { seed }\end{array}$ \\
\end{tabular} & $\begin{array}{c}\text { Germination } \\
\text { \%age }\end{array}$ \\
\hline 11123 & 1 & 12 & 80 & 11222 & 51 & 14 & 93 \\
\hline 11126 & 2 & 11 & 73 & 11223 & 52 & 11 & 73 \\
\hline 11144 & 3 & 14 & 93 & 11224 & 53 & 13 & 87 \\
\hline 11145 & 4 & 13 & 87 & 11225 & 54 & 11 & 73 \\
\hline 11152 & 5 & 14 & 93 & 11226 & 55 & 12 & 80 \\
\hline 11154 & 6 & 12 & 80 & 11227 & 56 & 14 & 93 \\
\hline 11155 & 7 & 11 & 73 & 11228 & 57 & 14 & 93 \\
\hline 11160 & 8 & 11 & 73 & 11229 & 58 & 15 & 100 \\
\hline 11161 & 9 & 15 & 100 & 11231 & 59 & 15 & 100 \\
\hline 11162 & 10 & 14 & 93 & 11233 & 60 & 11 & 73 \\
\hline 11163 & 11 & 13 & 87 & 11236 & 61 & 14 & 93 \\
\hline 11164 & 12 & 15 & 100 & 11237 & 62 & 12 & 80 \\
\hline 11166 & 13 & 14 & 93 & 11239 & 63 & 12 & 80 \\
\hline 11168 & 14 & 12 & 80 & 11240 & 64 & 13 & 87 \\
\hline 11170 & 15 & 13 & 87 & 11242 & 65 & 14 & 93 \\
\hline 11171 & 16 & 11 & 73 & 11243 & 66 & 14 & 93 \\
\hline 11173 & 17 & 11 & 73 & 11244 & 67 & 15 & 100 \\
\hline 11174 & 18 & 13 & 87 & 11246 & 68 & 14 & 93 \\
\hline 11177 & 19 & 14 & 93 & 11248 & 69 & 12 & 80 \\
\hline 11178 & 20 & 15 & 100 & 11249 & 70 & 13 & 87 \\
\hline 11179 & 21 & 13 & 87 & 11250 & 71 & 14 & 93 \\
\hline 11181 & 22 & 12 & 80 & 11252 & 72 & 12 & 80 \\
\hline 11183 & 23 & 14 & 93 & 11253 & 73 & 11 & 73 \\
\hline 11184 & 24 & 11 & 73 & 11255 & 74 & 13 & 87 \\
\hline 11185 & 25 & 12 & 80 & 11256 & 75 & 15 & 100 \\
\hline 11186 & 26 & 11 & 73 & 11259 & 76 & 14 & 93 \\
\hline 11187 & 27 & 12 & 80 & 11261 & 77 & 12 & 80 \\
\hline 11188 & 28 & 15 & 100 & 11265 & 78 & 12 & 80 \\
\hline 11189 & 29 & 15 & 100 & 11272 & 79 & 11 & 73 \\
\hline 11190 & 30 & 12 & 80 & 11274 & 80 & 14 & 93 \\
\hline 11192 & 31 & 15 & 100 & 11275 & 81 & 14 & 93 \\
\hline 11193 & 32 & 14 & 93 & 11278 & 82 & 13 & 87 \\
\hline 11194 & 33 & 12 & 80 & 11288 & 83 & 14 & 93 \\
\hline 11195 & 34 & 11 & 73 & 11290 & 84 & 13 & 87 \\
\hline 11197 & 35 & 14 & 93 & 11292 & 85 & 13 & 87 \\
\hline 11198 & 36 & 12 & 80 & 11293 & 86 & 13 & 87 \\
\hline 11200 & 37 & 13 & 87 & 11294 & 87 & 12 & 80 \\
\hline 11202 & 38 & 15 & 100 & 11295 & 88 & 14 & 93 \\
\hline 11205 & 39 & 12 & 80 & 11296 & 89 & 15 & 100 \\
\hline 11207 & 40 & 13 & 87 & 11297 & 90 & 15 & 100 \\
\hline 11208 & 41 & 12 & 80 & 11299 & 91 & 14 & 93 \\
\hline 11209 & 42 & 15 & 100 & 11304 & 92 & 11 & 73 \\
\hline 11210 & 43 & 14 & 93 & 11317 & 93 & 14 & 93 \\
\hline 11211 & 44 & 12 & 80 & 11553 & 94 & 12 & 80 \\
\hline 11214 & 45 & 12 & 80 & 11558 & 95 & 13 & 87 \\
\hline 11215 & 46 & 11 & 73 & 12087 & 96 & 14 & 93 \\
\hline 11216 & 47 & 13 & 87 & 12100 & 97 & 11 & 73 \\
\hline 11217 & 48 & 11 & 73 & 12231 & 98 & 12 & 80 \\
\hline 11218 & 49 & 13 & 87 & 18668 & 99 & 13 & 87 \\
\hline 11221 & 50 & 12 & 80 & 24740 & 100 & 11 & 73 \\
\hline
\end{tabular}

* Germination test was done prior to field evaluation

** Accessions with less than $70 \%$ germination were not selected in present study

For the evaluation morphological parameters RCB-Design was used with 3 replications across two locations i.e. in Islamabad (located at $33.6844^{\circ} \mathrm{N}$ and $73.04799^{\circ} \mathrm{E}$ ) and in Peshawar region (located at $34.01^{\circ} \mathrm{N}$ and $71.35^{\circ} \mathrm{E}$ ). The climate of the Islamabad region is a humid subtropical climate (Köppen climate classification. The temperature 
ranges from a minimum of $-3.9^{\circ} \mathrm{C}\left(25.0^{\circ} \mathrm{F}\right)$ in January to a maximum of $46.1{ }^{\circ} \mathrm{C}(115.0$ ${ }^{\circ} \mathrm{F}$ ) in June. The rainy period of the year lasts for 12 months, from November 19 to November 6, with a sliding 31-day rainfall of at least 0.5 inches. Most rain falls during the 31 days centered on July 29, with an average total accumulation of 7.4 inches.

Peshawar region lies $331 \mathrm{~m}$ above sea level and climate it's referred as a local steppe climate because there is not much rainfall all year long. The Köppen-Geiger climate classification is BSh. The temperature here averages $22.7^{\circ} \mathrm{C} \mid 72.8^{\circ} \mathrm{F}$. Precipitation here is about $384 \mathrm{~mm} \mid 15.1$ inch per year. In Peshawar sowing was done on the $20^{\text {th }}$ November while in Islamabad it was on the $1^{\text {st }}$ December. Furthermore, proper agronomic practices (one ploughing with soil turing plough followed by 2-3 harrowing) were followed in order to have data accuracy. Crop was planted when soil was in proper water condition. Plot size was $5 \mathrm{~m}^{2}$ while plant to plant distance was $10 \mathrm{~cm}$ and row to row distance was $18 \mathrm{~cm}$. Seed drill method with $5 \mathrm{~cm}$ depth with seed rate of $100 \mathrm{~kg} / \mathrm{ha}$ was used. Fertilizer treatment was $150 \mathrm{~kg} \mathrm{~N}+60 \mathrm{~kg} \mathrm{P}_{2} \mathrm{O}_{5}+40 \mathrm{~kg} \mathrm{~K} 2 \mathrm{O} / \mathrm{ha}$. Weeding was done when required by manual method in between the intervals while 2.4-D @ $500 \mathrm{~g}$ ai/ha in 700 liters of water was applied at 35-40 days after sowing.

Data was recorded by taking 5 samples from each replication on days to germination, $1^{\text {st }}$ leaf stage, $2^{\text {nd }}$ leaf stage, $3^{\text {rd }}$ leaf, booting, half boot, heading, fertilization leaf length and width, plant height, peduncle length, $1000 \mathrm{~g}$ seed weight and seed plant ${ }^{-1}$ were determined for principal component analysis.

SSR markers (Primer Invitrogen) were used for finding out rust genetic diversity on molecular basis. DNA extraction was done by commercially available kit (Fermintas) and Polymerase Chain Reaction (Applied Biosystems 96 well USA, model 9902) was carried out by the protocol as mentioned in (Begum et al., 2014). Twenty-two (11 each monomorphic and polymorphic) previously reported DNA markers XGWM35 (200\&225 bp), WMC419, XGWM120, GWM174, XGWM140, XWMC170, XWMC405, XWMC348, XWMC407 (Figure 1), GWM 148 (190\&200 bp), Barc 86 (200\&210 bp), WMC 773, BARC 114 (105\&200bp), CSLV34 (150\&190bp), PSP3000 (300\&350bp), XGWM493 (150\&300bp), XGWM153 (100\&300bp), XGWM111, XGWM44 with 120,285,500 \& 700bp (Figure 2), BARC4 (90\&200bp), XGWM125 (150\&190bp) and XGWM410 were employed to amplify PCR products (Table 2). PCR products were resolved in gel tank (Cleaver scientific LtD, made in UK serial Number MS 130711) on 4\% agarose gel and were stained with Ethidium Bromide. The fragments were visualized under UV light in the gel documentation system (Syngene) at NIGAB for identification. For proper assessment of data all data was compiled with recommended guidelines necessary for statistical analysis. The data were analyzed using Web-based software using SaaS application (McNee, 2007) statistical packages "R" version 4.0.2 (R Core Team, 2014).

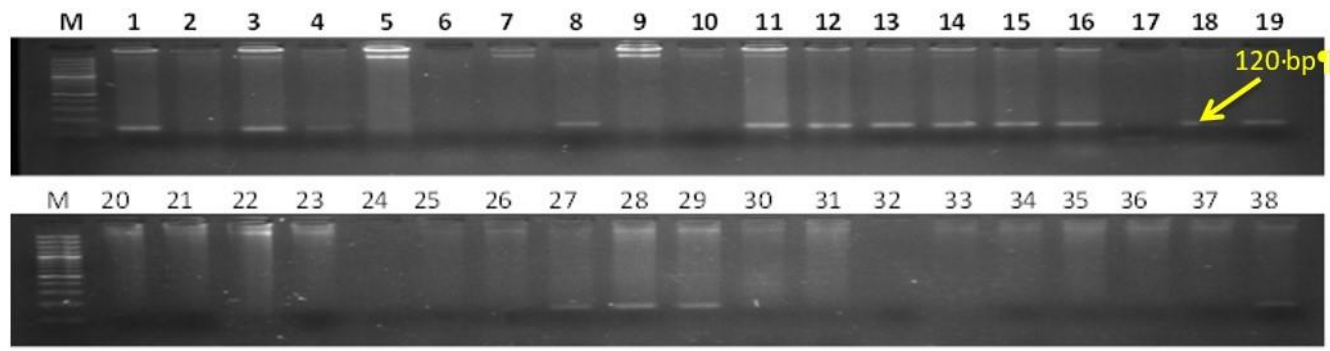

Figure 1: PCR confirmation of 1-38 accessions with XWMC 407 SSR marker(monomorphic) indication presence of $120 \mathrm{bp}$ bands size 


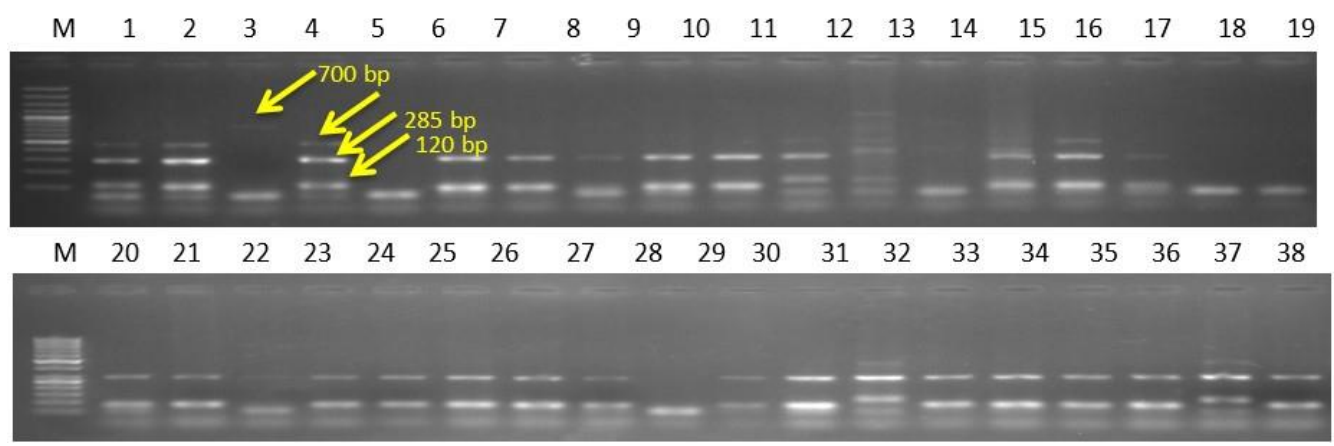

Figure 2: PCR confirmation of 1-38 accessions with XGWM 44 SSR marker (polymorphic) indication presence of 120-700 bp bands size

Table 2: List of applied markers with band size and target site used to detect rust resistance genes

\begin{tabular}{c|c|c|c|c|c}
\hline S.No & Marker & $\begin{array}{c}\text { Allelic variant } \\
\text { (Band size) }\end{array}$ & Target Gene/site & Polymorphism & Reference \\
\hline 1 & Barc 86 & $200 \& 210$ & Yr-26 & Yes & (Wang et al., 2008) \\
2 & WMC773 & 298 & Yr-26/Lr 38 & Yes & (Båga et al., 2007) \\
3 & BARC114 & $105 \& 200$ & 4 D chromosome & Yes & (Tékeu et al., 2017) \\
4 & XGDM125 & $150 \& 190$ & & Yes & (Abbasabad et al., 2017) \\
5 & XGWM35 & $200 \& 225$ & & & (Li et al., 2005) \\
6 & GWM174 & 220 & Yes & (Begum et al., 2014) \\
7 & CSLV34 & $150 \& 190$ & Yr-18/Lr34 & Yes & (Begum et al., 2014) \\
8 & PSP3000 & $300 \& 350$ & Yr-10 & & (Begum et al., 2014) \\
9 & WMC419 & 200 & Yr-29 & (Peng et al., 2000) \\
10 & XGWM140 & 120 & YrH52 et al., 2005) \\
11 & XGWM44 & $120,285,500 \& 700$ & Lr-19/Yr18 & Yes & (Luo et al., 2006) \\
12 & XGWM410 & 140 & YrCN19 & & (Begum et al., 2014) \\
13 & XGWM120 & 150 & Yr-5 & & (Chhuneja et al., 2008) \\
14 & XWmc 170 & 170 & 2A/stripe rust & & (Suenaga et al., 2003) \\
15 & XWMC405 & 220 & $7 D$ & & (Bansal et al., 2008) \\
16 & XWMC348 & 130 & Lr 49 & & (Wang et al., 2010) \\
17 & XWMC407 & 120 & Lr17 & (Börner et al., 2000) \\
18 & XGWM493 & $150 \& 300$ & 3B/stripe rust & Yes & (Yue et al., 2010) \\
19 & XGWM153 & $100 \& 300$ & YrP138 & Yes & (Carter et al., 2009) \\
20 & GWM148 & $190 \& 200$ & Lr60 & Yes & (Dawit et al., 2019) \\
21 & XGWM111 & 185 & Yr33/ yr 26 & & (Lillemo et al., 2008) \\
22 & BARC4 & $90 \& 200$ & Lr34/Yr18 \& Lr46/Yr29 & Yes & \\
\hline
\end{tabular}

\section{Results}

Analysis revealed highly significant variation for many of the traits, furthermore genotype by location interaction were also highly significant (Table S1-S8). For genotype results of days to germination, $1^{\text {st }}$ leaf emergence, $2^{\text {nd }}$ leaf, leaf width, days to plant maturity, height and peduncle length showed highly significant results. While significant results were observed for traits like $2^{\text {nd }}$ leaf, days to booting, days for half opening of spike, days to heading, days to fertilization, leaf length and seeds spike ${ }^{-1}$. Moreover, traits like spike length, number of spikelet spike ${ }^{-1}$, infertile spikelet spike ${ }^{-1}$, awn length, spike plant ${ }^{-1}$ (fertile tillers) and seeds plant $^{-1}$ showed non-significant variation. Similarly for genotype by location interaction results showed that highly 
significant variation were observed due to the environment for $1^{\text {st }}$ leaf emergence, $3^{\text {rd }}$ leaf, days to booting, half opening of spike, days to heading, days to fertilization, days to plant maturity and plant height traits, while non-significant variation were reported for traits like days to germination, $1^{\text {st }}$ leave emergence, $2^{\text {nd }}$ leaf, leaf length, leaf width, peduncle length, spike length, number of spikelet spike $^{-1}$, infertile spikelet spike ${ }^{-1}$, awn length, seeds spike ${ }^{-1}$, spike plant ${ }^{-1}$ (fertile tillers) and seeds plant ${ }^{-1}$.

All the significant environmental interactions are further explained in order to get the exact picture of genotypes performance for the selected locations. It's often difficult for a plant breeder to explain the extent of variation among large number of accession when assessed together. In order to effectively and reliably explain the extent of variation we have used statistical methods like PCA which will not only help us to explain the extent of variation but will help in the grouping of these accessions based on similarities and dissimilarities.

\section{Islamabad region}

The PCA was performed to find out the genetic base of accession (Figures 3, 4 and Table S9). Analysis revealed that PC1 was covering 96.7\% variation while PCA component 2 (PC2) was only accommodating $2.1 \%$ variation (Figure 3). PCA distributed all the lines in to three major clusters based on genetic diversity. Cluster III comprised of only one line (2), cluster II was having two lines (6 and 46), and the rest of the accessions (97\%) were clustered in cluster I based on their performance for the studied traits. Accessions 69, 7, 80, 29, 30, 91, 83, 92, 75, 81, 56, 82, 96, 93, 5, 65, 84, $27,82,96,93,73,95,19,94,31,11,97,62,54,100,18$ and 4 are all in quadrant (Plot C) and contained high diversity level.

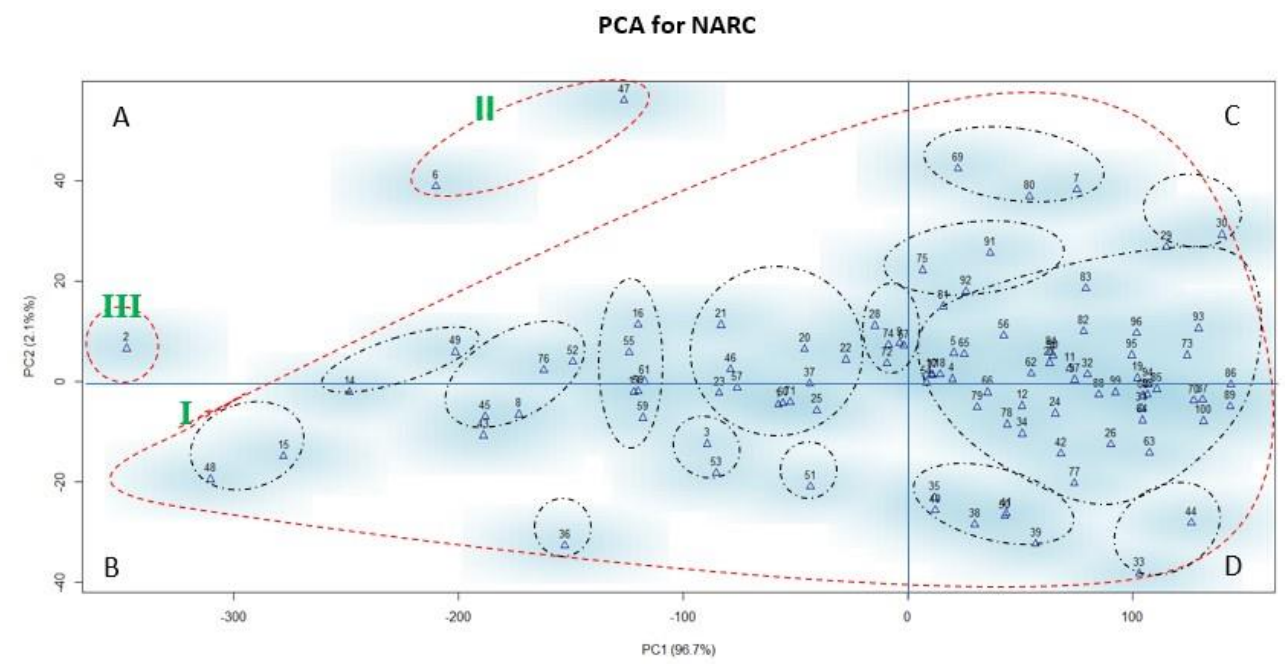

Figure 3. PCA analysis of yield related traits forl00 indigenous lines for Location A (NARC Islamabad field)

\section{Peshawar region}

Analysis revealed that PC1 was explaining 80.1\% variation while component 2 (PC2) was having 15.6\% variation (Figure 4). PCA grouped all lines into five clusters. Cluster IV and V comprised of only one line i.e. 36 and 47 respectively, cluster III was 
having two lines (52 and 92), cluster II was having 8 accessions $(6,7,30,69,80,91,95$ and 93), while the rest of the accessions (87\%) were clustered in cluster I based on their performance for the studied traits.

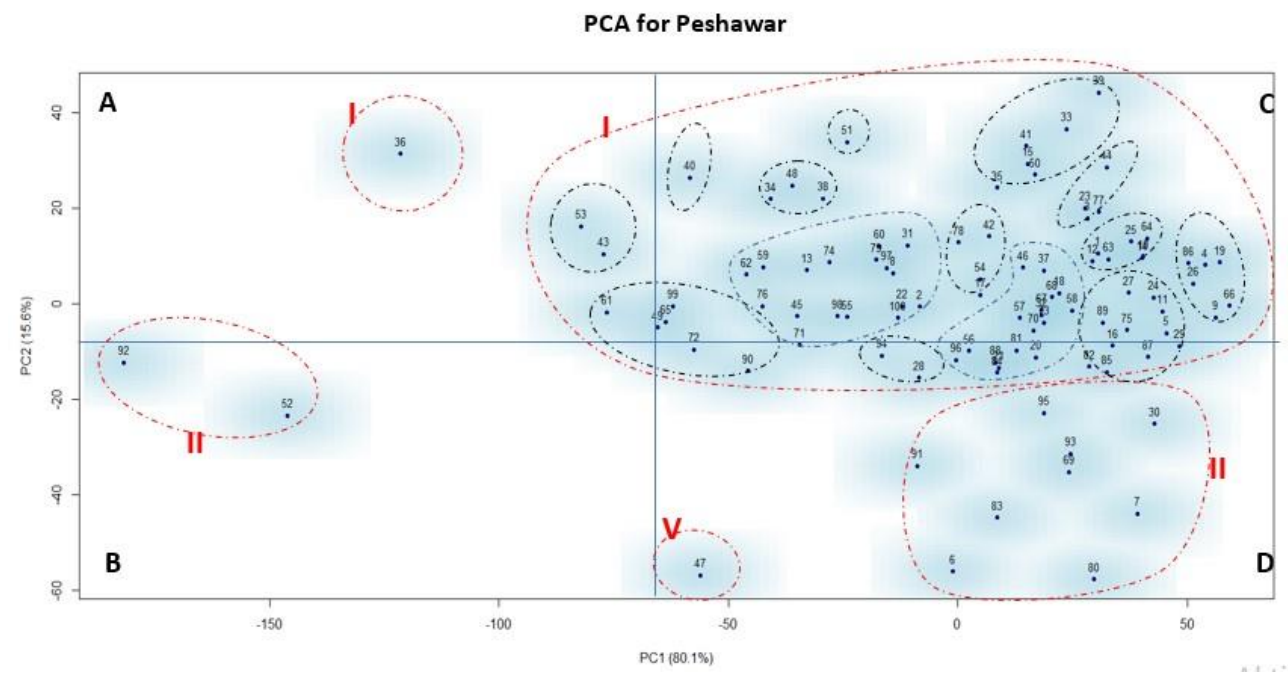

Figure 4. PCA analysis of yield related traits for 100 indigenous lines for Location B (Peshawar)

Furthermore, PCA analysis at both locations showed diversification of accession along with random pattern confirming broad genetic base and least similarity among the accessions with desired performance for most of the accessions in $3^{\text {rd }}$ quadrant (Plot C) along with high genetic diversity compared to other quadrants.

Most of the accessions were found in positive quadrant $(\mathrm{C})$ proving them to have broad genetic base with ideal performance for all traits except those where lower mean values are preferred. Each quadrant accessions were different from other quadrant. Remaining germplasm had random pattern confirming broad genetic base. The germplasm in plot B and D also exhibited the diversity were poor in performance for studied traits where higher mean value is required. Moreover, accessions were randomly arranged in quadrant $\mathrm{B}$ and $\mathrm{C}$ containing some outliers as well proving that more data of these particular accessions are required in order to link them clearly to quadrant C.

\section{Cluster analysis based on SSR}

A total of 22 SSR (mono/polymorphic) were used to detect rust resistance genes/alleles. A total of 36 reproducible bands were reported. Data was documented on the bases of detection of specific band sizes (Tables S9 and S10). Bands frequency ranged from 5-21. A total of 23 land races were identified with the presence of nearly $50 \%$ bands frequency for SSR markers. Accessions 4, 8, 12, 26, 49, 68, 83 and 84 were having 17 score able bands out of 36. Similarly accessions 2, 6, 11, 14, 22, 27, 30, 31, 32, 38, 51 and 98 were having 18 score able bands, while accessions 24, 25 and 29, 52 had 19 and 21 score able bands respectively. A dendrogram was constructed on the basis of coefficient of dissimilarity to find out genetic diversity in indigenous germplasm. High level of diversity was observed i.e. two main groups were revealed (A and B). Group A was only having $36 \%$ of the total accessions while the rest of the accessions were grouped in B shown in (Table 3). Both groups were dissimilar with 
Euclidian value of 10 . Both the groups were divided into two sub-groups i.e. A-1, A-2 and B-1 and B-2 respectively (Table 3 and Figure 5). A-1 and A-2 were 80 percent dissimilar (Euclidian value 0.8) while sub-groups B-1 and B-2 were 90\% distinct. Apart from sub-group A-1, all were subdivided into 2 clusters each.

Table 3: Distribution of 100 accessions into groups and clusters by cluster analysis on the basis of 22 SSR (mono/polymorphic) markers

\begin{tabular}{|c|c|c|c|c|c|}
\hline S.No & Groups & Cluste & bcluster & Accessions number & Total $(\%)$ \\
\hline \multirow{3}{*}{1} & \multirow{3}{*}{ A } & \multicolumn{2}{|c|}{$\mathrm{A}-1^{*}$} & $81,84,48,50$ & 4 \\
\hline & & \multirow{2}{*}{ A-2 } & A-2-1 & $\begin{array}{c}79,92,75,33,91,35,80,77,21,34,44,78 \\
88,89,55,25,36\end{array}$ & 17 \\
\hline & & & A-2-2 & $\begin{array}{c}28,85,32,87,94,26,23,30,95,7,93,16 \\
19,27,57\end{array}$ & 15 \\
\hline \multirow{4}{*}{2} & \multirow{4}{*}{ B } & \multirow[b]{2}{*}{ B-1 } & B-1-1 & $\begin{array}{c}61,66,99,100,11,8,98,97,73,59,63,62 \\
65,83,20,10,22,29,60,68,86 \\
\end{array}$ & 21 \\
\hline & & & B-1-2 & $\begin{array}{c}4,56,9,74,69,18,17,13,1,5,15,14,2,12 \\
96,31,37,76,6,58,64,3,38,82,72,24,70 \\
67,71\end{array}$ & 29 \\
\hline & & \multirow{2}{*}{ B-2 } & B-2-1 & $43,39,90,40,41,46$ & 6 \\
\hline & & & B-2-2 & $49,53,51,42,45,52,47,54$ & 8 \\
\hline
\end{tabular}

**Grouping of accessions are based on similarity in terms of the presence of same band sizes for each SSR marker

*Cluster A-1 has no sub-cluster due to least of all accessions

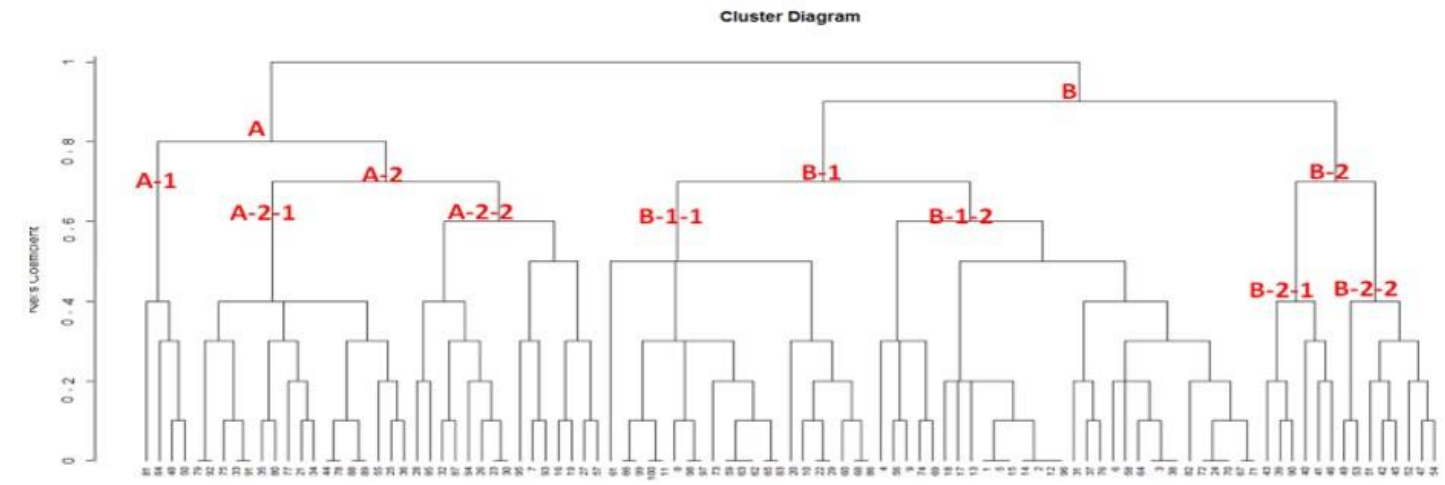

Figure 5: Dendrogram showing Distribution of 100 accessions in to groups and clusters on the basis of 22 SSR markers

Cluster B-1-1, B-1-2 and B-2-2, B-2-2 were almost 70\% dissimilar to each other. B-1 was the largest subgroup containing $50 \%$ of the total accessions. Similarly cluster B-1-1 was the biggest of all with 29 accessions. The cluster grouped different accessions in terms of the presence of multiple alleles detected by 24 SSR markers for rust resistance (Figure 5). 


\section{Discussion}

Most agronomic traits are affected by the varying environment, due to which genetic basis dissection becomes very difficult (Wang et al., 2017). Genetic diversity is partially depleting as the breeding only focuses on yield related parameters (Ren et al., 2013; Mengistu et al., 2016b) which is of serious concern as narrowing the genetic base of wheat could be disastrous in fighting climate change and other yield related parameters or disease related issues. Present study was performed in order to find out genetic diversity on morphological traits as wells as for rust resistance genes. Similarly results effect due to location, varieties and $\mathrm{G} \times \mathrm{E}$ was also addressed for the indigenous population. Pooled ANOVA for RCBD showed highly significant variations in all three compartments (location, varieties and $\mathrm{G} \times \mathrm{E}$ ) proving the locations and germplasm diversity. Principal Component Analysis can be used for multi-location trials effectively for genetic diversity (Bhanupriya et al., 2014; Mengistu et al., 2016a; Devesh et al., 2019). The PCA results are a bit different from Mengistu and Dvesh as their results showed $80 \%$ variation by PC compartments. PC plot proved high genetic diversity but it also suggested that the landrace lot of variability structure and consisted of exceedingly admixed lineages. Results of Gordon et al. (2019) and Meena et al. (2014) were slightly different as PC1 to PC7 showed $79.85 \%$ of the total variation. Though PCA explained the variation among germplasm in both the studies the difference in the detected variation depends on the source of the dataset used in the study. Similarities or dissimilarities among germplasm can be identified by cluster analysis on the basis of genetic distance between groups and clusters. All the accessions within one cluster are genetically similar while genetically dissimilar to other cluster. Results of our study are also in line with Chen et al. (2012) and Islam et al. (2012) who found different clusters and subgroups according to geographical zones of ninety wheat accessions with 269 SSR. Rust species specific alleles in crop can be easily recognized by comparing their lethality or resistance to different pathotypes. The accessions that are having more resistance gene combination must be explored further in breeding germplasm with available rust markers (Sadiq, 2019). In order to increase the biodiversity of Pakistani germplasm, present study was design to broaden the genetic base of our existing varieties by identifying accessions with rust resistant genes.

\section{Yellow rust resistance}

Rust resistance gene $\operatorname{Yr} 5$ is present on $2 \mathrm{BL}$ chromosome and was transferred to bread wheat from spelt wheat. Xgwm 120 marker, that is present at a $12 \mathrm{cM}$ distance from $\mathrm{Yr} 5$ (Begum et al., 2014), showed a 150-bp fragment in 54\% of wheat land races. Similarly, YrlO (stripe rust resistance gene) is dominant as well as race specific and was mapped on 2BS chromosome of wheat. At present psp3000 marker is the only one available for Yr10. The distance between both marker and gene is $1.2 \mathrm{cM}$ (Begum et al., 2014). Amplification of PCR product produced polymorphic band i.e. $300 \mathrm{bp}$ and $350 \mathrm{bp}$ fragment in $43 \%$ of population. Moreover, the co-dominant nature of this marker is considered ideal for $\mathrm{Yr} 10$ gene identification in segregating population. Australian germplasm was also successfully screened by this marker (Bariana et al., 2002).

Locus Yr18 and Lr34 confer slow rusting to stripe and leaf rust (Begum et al., 2014). The csLV34 marker (Lagudah et al., 2006) amplified 150bp and 190bp fragment in 16\% of the genotypes proving presence of $\operatorname{Yr} 18$ gene, whereas a $215 \mathrm{bp}$ size was associated with the nonappearance of $\operatorname{Yrl} 8$ was successfully able to amply in 53\% of total 
population. The rest of land races didn't amplify any of the bands. This marker is codominant which makes them suitable for use in early segregating generations. The frequency of this gene is quite low in Pakistani population as previously reported (Begum et al., 2014) hence there is dire need to broaden the race-nonspecific resistance for yellow rust. Similarly, results were also observed previously (Begum et al., 2019) where all advanced wheat lines were checked by CSLV34 for presence of Lr34/Yr18 that yielded a PCR product of $150 \mathrm{bp}$ amplification in $43 \%$ of the accessions.

Two markers Barc 86 (200bp) and Wmc 773 (298bp) were used to detect the presence of $Y r 26$ gene. Former showed its presence in 94 accessions while the latter was detected in 74 accessions out of the total population. Wheat genotypes with $Y r 26$ gene were found resistant to majority of Pst races in virulent tests (Wang et al., 2008). However, virulence against this gene has recently been detected in Australia. Pyramiding of this gene with other $Y r$ genes may be helpful to broaden the genetic base of wheat against Pst. Three other markers were used to detect presence of $\operatorname{Yr} 29$ gene. Wmc 419 (200bp) showed its presence in 55\% of the population while xgwm 140 (120bp) and xgwm 410 (140 bp) were present in 56 and $45 \%$ of the landraces, respectively. Similar results were obtained by Begum et al. (2014) for Yr26 and 29 and genes. The $\mathrm{Yr}$ resistance for barc4 (90-100bp) is located on arm 5BS of the chromosome (Law and Worland, 1997), similarly Maccaferri et al. (2015) reported that it is associated with genetic resistance for yellow rust but Lillemo et al. (2008) was able to find a significant Quantitative trait locus (QTL) for Powdery mildew resistance on 5BS,close to the SSR marker Xbarc4. STS markers Xgwm111 with a band size of $185 \mathrm{bp}$ was detected in $70 \%$ of the population. This marker is considered more reliable for $\mathrm{Yr}$ identification (Sadiq, 2019) that is linked to $Y r 15$ and 26 with a distance of $1.9 \mathrm{cM}$ (Ma et al., 2001). This marker has been also reported to be linked with Yr33 as well (Dawit et al., 2019).

The marker Xgwm148 (190-200 bp) is associated with high-temperature adult-plant resistance to stripe rust resistance in spring wheat, present on 2BS chromosome in between a $16.9 \mathrm{cM}$ region (Carter et al., 2009). Its $190 \mathrm{bp}$ and $200 \mathrm{bp}$ allele was detected in $63 \%$ and $13 \%$ population respectively in present study. Marker for locus $\mathrm{xwmc} 170-2 \mathrm{~A}$ is associated to stripe rust resistance. It was maped on chromosome $2 \mathrm{~A}$ of T. monococcum within $3.6 \mathrm{cM}$ distance for Xwmc407 and Xwmc170 marker (Chhuneja et al., 2008). In the present study Xwmc407 was identified in 60 out of 100 land races proving that the majority of germplasm was having resistant genes. Microsatellite marker xwmc348 (130bp) was screened in 31 of the land races confirming the presence of $\operatorname{Lr} 49$ in this population. Previously the same was reported by Bansal et al. (2008) as well. Xgwm153 (100bp and 300bp) was present in almost $82 \%$ of the population. It is $8.2 \mathrm{cM}$ away from the YrP138 resistance gene. This is quite different from other known resistance as it shows resistance to the prevailing Chinese Pst raceCYR32 at seedling stage (Yue et al., 2010). The marker Xgwm493 is present on the short arm of chromosome 3BS indicating the location of the stripe rust resistance gene (Börner et al., 2000) was able to detect the presence of $\mathrm{Sr}$ resistance gene in 57\% (150 bp) and 66\% (300bp) of land races.

\section{Leaf rust resistance}

Microsatellite markers barc 114 is present on chrosome 4D (Båga et al., 2007) amplified 105-200 bp band, xgwm 165 (225 bp), gwm 174 (220bp) and xgwm 125 (150-190 bp) were used to detect this gene. These markers identified 85, 62, 1, 55 land 
races with $\operatorname{Lr} 34$ gene, respectively. Xgwm 125 marker has been previously used for genetic diversity as well (Tékeu et al., 2017). Similarly, marker Xgwm35 has been previously used for genetic diversity as well (Abbasabad et al., 2017). Xgwm44 (185 bp) is closely linked to $\operatorname{Lr} 19$ (Li et al., 2005) gene and is broadly used for its detection and is also used for maping of gene (Xing et al., 2006) was able to screen $66 \%$ of the population. This marker was also reported to be linked with $\operatorname{Yr} 18$ gene (Imtiaz et al., 2004). Marker Xwmc407 (120 bp) was used to detect $\operatorname{Lr} 17$ in $42 \%$ of the population used in present study, which is flanked by this marker that is on the short-arm of wheat 2A chromosome (Wang et al., 2010). But it is also widely used to examine the presence of Yr17 gene (Sadiq, 2019). Suenaga et al. (2003) mentioned the linkage between stripe and leaf rust severity detected by the marker Xwmc405 which is present on chromosome 7D. Its allele of $120 \mathrm{bp}$ was in 81 land races proving that these lines can be used for developing both leaf and stripe rust resistant varieties. But reports suggest that this marker is also linked to other traits as well (Golabadi et al., 2011).

\section{Conclusion and Recommendations}

Results indicated high level of diversity in studied pool of indigenous lines which can be used for creating varieties for any desired traits. Based on marker results, 23 wheat lines ranging 17-21 alleles in combination were identified. Durable resistance in the present study was a bit low making it compulsory that these selected land races should be used in future breeding programs as donor parents to increase gene frequency for broadening the available genetic base of Pakistani varieties that will be newly developed. Over the last three decades, rust has destroyed yield of wheat crop significantly therefore, there is a need to develop lines by pyramiding of gene pool in our varieties. This study will ultimately help in yield enhancement, moreover the study discovered the presence of variability among the tested genotypes for rust resistance genes and confirmed possibility for increasing wheat productivity in the target area by incorporating these diversified lines in future breeding programs. Combined PCA and SSR provides sufficient power in identifying diversity at phenotypic and genetic level, thus providing a better chance to plant breeders and geneticists to select desirable genotypes out of base population with unknown diversity or variability. Our results highly recommended that these land races must be evaluated with more number of markers linked to all available pool of rust resistant genes. Furthermore, gene sequencing of these lines for the marker that showed allelic variations are also recommended for finding our desirable gene combination that will be a great assistance in developing future wheat varieties.

Acknowledgements. The Government of Pakistan funded the study through NIGAB project 'National Institute for Genomics and Advanced Biotechnology'. All the authors are thankful to the National Agricultural Research Centre and Crop Diseases Research Program Islamabad Pakistan for providing seeds and guidance. The authors are obliged to Assistant Professor Dr Sajid Ali (Institute of Biotechnology \& Genetic Engineering (IBGE) for assistance in rust validation and Mr. Zabih Ullah (Department of Plant Breeding \& Genetics, Faculty of Crop Production Sciences, The University of Agriculture, Peshawar, Pakistan) for assisting statistical analysis in the present study. 


\section{REFERENCES}

[1] Abbasabad, E. Z., Mohammadi, S. A., Moghaddam, M., Kamali, M. R. J. (2017): Analysis of genetic diversity, population structure and linkage disequilibrium in Iranian wheat landraces using SSR markers. - Plant Genetic Resources 15: 327.

[2] Ajmal, S. U., Minhas, N. M., Hamdani, A., Shakir, A., Zubair, M., Ahmad, Z. (2013): Multivariate analysis of genetic divergence in wheat (Triticum aestivum) germplasm. Pak. J. Bot. 45: 1643-1648.

[3] Båga, M., Chodaparambil, S. V., Limin, A. E., Pecar, M., Fowler, D. B., Chibbar, R. N. (2007): Identification of quantitative trait loci and associated candidate genes for lowtemperature tolerance in cold-hardy winter wheat. - Functional \& Integrative Genomics 7: 53-68.

[4] Bansal, U. K., Hayden, M. J., Venkata, B., Khanna, R., Saini, R., Bariana, H. S. (2008): Genetic mapping of adult plant leaf rust resistance genes Lr48 and Lr49 in common wheat. - Theoretical and Applied Genetics 117: 307-312.

[5] Bariana, H., Brown, G., Ahmed, N., Khatkar, S., Conner, R., Wellings, C., Haley, S., Sharp, P., Laroche, A. (2002): Characterisation of Triticum vavilovii-derived stripe rust resistance using genetic, cytogenetic and molecular analyses and its marker-assisted selection. - Theoretical and Applied Genetics 104: 315-320.

[6] Begum, S., Iqbal, M., Ahmed, I., Fayyaz, M., Shahzad, A., Ali, G. M. (2014): Allelic variation at loci controlling stripe rust resistance in spring wheat. - Journal of genetics 93: 579-586.

[7] Bhanupriya, B., Satyanarayana, N., Mukherjee, S., Sarkar, K. (2014): Genetic diversity of wheat genotypes based on principal component analysis in Gangetic alluvial soil of West Bengal. - J. Crop Weed 10: 104-107.

[8] Börner, A., Röder, M., Unger, O., Meinel, A. (2000): The detection and molecular mapping of a major gene for non-specific adult-plant disease resistance against stripe rust (Puccinia striiformis) in wheat. - Theoretical and Applied Genetics 100: 1095-1099.

[9] Brown, J. K., Hovmøller, M. S. (2002): Aerial dispersal of pathogens on the global and continental scales and its impact on plant disease. - Science 297: 537-541.

[10] Carter, A. H., Chen, X., Garland-Campbell, K., Kidwell, K. K. (2009): Identifying QTL for high-temperature adult-plant resistance to stripe rust (Puccinia striiformis f. sp. tritici) in the spring wheat (Triticum aestivum L.) cultivar 'Louise'. - Theoretical and Applied Genetics 119: 1119-1128.

[11] Cgiar, I. A. U. (2017): Project Management, Good Practice Note, Smb-Arc-08. - Project Management, Good Practice Note, Smb-Arc-08, Version: July2017. Https://www. CGIAR. O Org/Wp/WpContent/Uploads/2018/01/Gpn-Project-Management-July-2017. Pdf.

[12] Chen, X., Min, D., Yasir, T. A., Hu, Y.-G. (2012): Genetic diversity, population structure and linkage disequilibrium in elite Chinese winter wheat investigated with SSR markers. - PLOS one 7: e44510.

[13] Chhuneja, P., Kaur, S., Garg, T., Ghai, M., Kaur, S., Prashar, M., Bains, N., Goel, R., Keller, B., Dhaliwal, H. (2008): Mapping of adult plant stripe rust resistance genes in diploid A genome wheat species and their transfer to bread wheat. - Theoretical and Applied Genetics 116: 313-324.

[14] Dawit, W., Badebo, A., Hunde, B., Kassa, D., Röder, M. (2019): Haplotype analysis of Ethiopian bread wheat (Triticum aestivum) cultivars and elite lines for yellow rust resistance genes using linked molecular markers. - African Journal of Biotechnology 18: 37-57.

[15] Devesh, P., Moitra, P., Shukla, R., Pandey, S. (2019): Genetic diversity and principal component analyses for yield, yield components and quality traits of advanced lines of wheat. - Journal of Pharmacognosy and Phytochemistry 8: 4834-4839. 
[16] Golabadi, M., Arzani, A., Maibody, S. M., Tabatabaei, B. S., Mohammadi, S. (2011): Identification of microsatellite markers linked with yield components under drought stress at terminal growth stages in durum wheat. - Euphytica 177: 207-221.

[17] Gordon, E., Kaviani, M., Kagale, S., Payne, T., Navabi, A. (2019): Genetic diversity and population structure of synthetic hexaploid-derived wheat (Triticum aestivum L.) accessions. - Genetic Resources and Crop Evolution 66: 335-348.

[18] Goutam, U., Kukreja, S., Tiwari, R., Chaudhury, A., Gupta, R., Dholakia, B., Yadav, R. (2013): Biotechnological approaches for grain quality improvement in wheat: present status and future possibilities. - Australian Journal of Crop Science 7: 469.

[19] Granato, D., Santos, J. S., Escher, G. B., Ferreira, B. L., Maggio, R. M. (2018): Use of principal component analysis (PCA) and hierarchical cluster analysis (HCA) for multivariate association between bioactive compounds and functional properties in foods: A critical perspective. - Trends in Food Science \& Technology 72: 83-90.

[20] Granato, D., Barba, F. J., Bursać Kovačević, D., Lorenzo, J. M., Cruz, A. G., Putnik, P. (2020): Functional foods: Product development, technological trends, efficacy testing, and safety. - Annual Review of Food Science and Technology 11: 93-118.

[21] Imtiaz, M., Ahmad, M., Cromey, M., Griffin, W., Hampton, J. (2004): Detection of molecular markers linked to the durable adult plant stripe rust resistance gene Yr18 in bread wheat (Triticum aestivum L.). - Plant Breeding 123: 401-404.

[22] Islam, S., Haque, M., Emon, R., Islam, M., Begum, S. (2012): Molecular characterization of wheat (Triticum aestivum L.) genotypes through SSR markers. - Bangladesh Journal of Agricultural Research 37: 389-398.

[23] Lagudah, E., McFadden, H., Singh, R., Huerta-Espino, J., Bariana, H., Spielmeyer, W. (2006): Molecular genetic characterization of the Lr34/Yr18 slow rusting resistance gene region in wheat. - Theoretical and Applied Genetics 114: 21-30.

[24] Law, C., Worland, A. (1997): The control of adult-plant resistance to yellow rust by the translocated chromosome 5BS-7BS of bread wheat. - Plant breeding 116: 59-63.

[25] Li, X., Yang, W.-X., Li, Y.-N., Liu, D.-Q., Yan, H.-F., Meng, Q.-F., Zhang, T. (2005): A SSR marker for leaf rust resistance gene Lr19 in wheat. - Scientia Agricultura Sinica 38: 1156-1159.

[26] Lillemo, M., Asalf, B., Singh, R., Huerta-Espino, J., Chen, X., He, Z., Bjørnstad, Å. (2008): The adult plant rust resistance loci Lr34/Yr18 and Lr46/Yr29 are important determinants of partial resistance to powdery mildew in bread wheat line Saar. Theoretical and Applied Genetics 116: 1155-1166.

[27] Luo, P., Zhang, H., Zhang, H., Ren, Z. (2006): Diagnostic detection and genetic analysis of wheat stripe rust resistant gene YrCN19. - Fen zi xi bao sheng wu xue bao = Journal of Molecular Cell Biology 39: 217-222.

[28] Ma, J., Zhou, R., Dong, Y., Wang, L., Wang, X., Jia, J. (2001): Molecular mapping and detection of the yellow rust resistance gene Yr26 in wheat transferred from Triticum turgidum L. using microsatellite markers. - Euphytica 120: 219-226.

[29] Maccaferri, M., Zhang, J., Bulli, P., Abate, Z., Chao, S., Cantu, D., Bossolini, E., Chen, X., Pumphrey, M., Dubcovsky, J. (2015): A genome-wide association study of resistance to stripe rust (Puccinia striiformis f. sp. tritici) in a worldwide collection of hexaploid spring wheat (Triticum aestivum L.). - G3: Genes, Genomes, Genetics 5: 449-465.

[30] McNee, W. S. (2007): SaaS 2.0. - Journal of Digital Asset Management 3: 209-214.

[31] Mebrate, S., Oerke, E., Dehne, H., Pillen, K. (2008): Mapping of the leaf rust resistance gene Lr38 on wheat chromosome arm 6DL using SSR markers. - Euphytica 162: 457466.

[32] Meena, N., Mishra, V., Baranwal, D., Singh, A., Rai, V., Prasad, R., Arun, B., Chand, R. (2014): Genetic evaluation of spring wheat (Triticum aestivum L.) recombinant inbred lines for spot blotch (Bipolaris Sorokiniana) resistance and yield components under natural conditions for South Asia. - Journal of Agricultural Science and Technology 16: 1429-1440. 
[33] Mengistu, D., Kidane, Y. G., Fadda, C., Pè, M. E. (2016a): Genetic diversity in Ethiopian durum wheat (Triticum turgidum var durum) inferred from phenotypic variations. - Plant Genetic Resources 16(1): 39-49.

[34] Mengistu, D. K., Kidane, Y. G., Catellani, M., Frascaroli, E., Fadda, C., Pè, M. E., Dell'acqua, M. (2016b): High-density molecular characterization and association mapping in Ethiopian durum wheat landraces reveals high diversity and potential for wheat breeding. - Plant Biotechnology Journal 14: 1800-1812.

[35] Peng, J. H., Fahima, T., Röder, M., Li, Y., Grama, A., Nevo, E. (2000): Microsatellite high-density mapping of the stripe rust resistance gene YrH52 region on chromosome 1B and evaluation of its marker-assisted selection in the F2 generation in wild emmer wheat. - New Phytologist 146: 141-154.

[36] Punjabi, B., Basu, R. (1982): Testing germination and seedling growth by an inclined glass plate blotter method. - Indian Journal of Plant Physiology 25: 289-295.

[37] Ren, J., Sun, D., Chen, L., You, F. M., Wang, J., Peng, Y., Nevo, E., Sun, D., Luo, M.-C., Peng, J. (2013): Genetic diversity revealed by single nucleotide polymorphism markers in a worldwide germplasm collection of durum wheat. - International Journal of Molecular Sciences 14: 7061-7088.

[38] Sadiq, M. (2019): Molecular screening of stripe rust resistance genes in segregating wheat populations and its evaluation in the field. - University of the Punjab, Lahore.

[39] Singh, R. P., William, H. M., Huerta-Espino, J., Rosewarne, G. (2004): Wheat rust in Asia: meeting the challenges with old and new technologies. - Proceedings of the $4^{\text {th }}$ International Crop Science Congress, The Regional Institute Ltd Gosford, Australia.

[40] Suenaga, K., Singh, R., Huerta-Espino, J., William, H. (2003): Microsatellite markers for genes Lr34/Yr18 and other quantitative trait loci for leaf rust and stripe rust resistance in bread wheat. - Phytopathology 93: 881-890.

[41] Tékeu, H., Ngonkeu, E. M., Djocgoué, F. P., Ellis, A., Lendzemo, V., Springfield, L., Moulin, L., Klonowska, A., Diouf, D., Botes, W. C. (2017): Genetic diversity of Cameroonian bread wheat (Triticum aestivum L.) cultivars revealed by microsatellite markers. - African Journal of Biotechnology 16: 1832-1839.

[42] Wang, C., Zhang, Y., Han, D., Kang, Z., Li, G., Cao, A., Chen, P. (2008): SSR and STS markers for wheat stripe rust resistance gene Yr26. - Euphytica 159: 359-366.

[43] Wang, Y., Peng, H., Liu, G., Xie, C., Ni, Z., Yang, T., Liu, Z., Sun, Q. (2010): Identification and molecular mapping of a leaf rust resistance gene in spelt wheat landrace Altgold. - Euphytica 174: 371-375.

[44] Wang, X., Luo, G., Yang, W., Li, Y., Sun, J., Zhan, K., Liu, D., Zhang, A. (2017): Genetic diversity, population structure and marker-trait associations for agronomic and grain traits in wild diploid wheat Triticum urartu. - BMC plant biology 17: 112.

[45] Waqar, A., Khattak, S. H., Begum, S., Rehman, T., Shehzad, A., Ajmal, W., Zia, S. S., Siddiqi, I., Ali, G. M. (2018): Stripe Rust: A Review of the Disease, Yr Genes and its Molecular Markers. - Sarhad Journal of Agriculture 34.

[46] Xing, L., Yang, W.-X., Li, Y.-N., Liu, D.-Q., Yan, H.-F., Meng, Q.-F., Zhang, T. (2006): A SSR marker for leaf rust resistance gene Lr19 in wheat. - Agricultural Sciences in China 5: 111-115.

[47] Yue, Y.-L., Yao, Z.-J., Ren, X.-X., Li, W. (2010): Molecular mapping of a gene for resistance to stripe rust in wheat variety PIW138. - Agricultural Sciences in China 9: $1285-1291$ 


\section{SUPPLEMENTAL DATA}

Table S1. Analysis of variance (RCB design) of Germination for 100 selected accessions with three replications across two locations for environmental interactions

\begin{tabular}{c|c|c|c|c|c|c|c}
\hline SOV & DF & SS & \%SS & MS & F-Cal & F-Tab @ 0.05 & F-Tab @ 0.01 \\
\hline Locations & 1 & 3788.85 & 0.51 & 3788.85 & 47.942364 & 7.71 & 21.1976895 \\
Reps w/n Loc & 4 & 316.117 & & 79.0292 & & & \\
Genotypes & 99 & 2181.08 & 0.30 & 22.0312 & 9.2770415 & 1.28 & 1.42312627 \\
GxL & 99 & 159.097 & 0.021 & 1.60704 & 0.6767063 & 1.28 & 1.42312627 \\
Pool Error & 396 & 940.424 & 0.127 & 2.37481 & & & \\
Total & 599 & 7385.57 & & & & & \\
\hline
\end{tabular}

*F-Cal $\geq$ F-Tab 0.01= Highly Significant, F-Cal $\geq$ F-Tab 0.05= Significant, F-Cal $<$ F-Tab $0.05=$ Nonsignificant

Table S2. Analysis of variance (RCB design) of Days to heading for 100 selected accessions with three replications across two locations for environmental interactions

\begin{tabular}{c|c|c|c|c|c|c|c}
\hline SOV & DF & SS & SS\% & MS & F-Cal & F-Tab @ 0.05 & F-Tab @ 0.01 \\
\hline Locations & 1 & 87865.8 & 0.669094 & 87865.8 & 370.12083 & 7.71 & 21.19768 \\
Reps w/n Loc & 4 & 949.591 & & 237.3977 & & & \\
Genotypes & 99 & 35162.3 & 0.267759 & 355.175 & 27.961729 & 1.28 & 1.423126 \\
GxL & 99 & 2312.83 & 0.017612 & 23.3619 & 1.8392072 & 1.28 & 1.423126 \\
Pool Error & 396 & 5030.06 & 0.038304 & 12.7021 & & & \\
Total & 599 & 131320. & & & & & \\
\hline
\end{tabular}

$*$ F-Cal $\geq$ F-Tab 0.01= Highly Significant, F-Cal $\geq$ F-Tab 0.05= Significant, F-Cal $<$ F-Tab 0.05= Nonsignificant

Table S3. Analysis of variance (RCB design) of Days to maturity for 100 selected accessions with three replications across two locations for environmental interactions

\begin{tabular}{c|c|c|c|c|c|c|c}
\hline SOV & DF & SS & SS\% & MS & F-Cal & F-Tab @ 0.05 & F-Tab @ 0.01 \\
\hline Locations & 1 & 188659.8 & 0.823797 & 188659.8 & 547.3080002 & 7.71 & 21.19768958 \\
Reps w/n Loc & 4 & 1378.82 & & 344.705 & & & \\
Genotypes & 99 & 29695.4 & 0.12966 & 299.953 & 19.713824 & 1.28 & 1.4231262 \\
GxL & 99 & 3253.07 & 0.01420 & 32.8593 & 2.1596064 & 1.28 & 1.4231262 \\
Pool Error & 396 & 6025.29 & 0.02631 & 15.2154 & & & \\
Total & 599 & 229012.4 & & & & & \\
\hline
\end{tabular}

F-Cal $\geq$ F-Tab $0.01=$ Highly Significant, F-Cal $\geq$ F-Tab $0.05=$ Significant, F-Cal $<$ F-Tab $0.05=$ Nonsignificant

Table S4. Analysis of variance (RCB design) of spike length for 100 selected accessions with three replications across two locations for environmental interactions

\begin{tabular}{c|c|c|c|c|c|c|c}
\hline SOV & DF & SS & SS\% & MS & F-Cal & F-Tab @ 0.05 & F-Tab @ 0.01 \\
\hline Locations & 1 & 0.000417 & 0.00000028 & 0.000417 & $1.70869 \mathrm{E}-05$ & 7.71 & 21.19768958 \\
Reps w/n Loc & 4 & 97.54047 & & 24.38512 & & & \\
Genotypes & 99 & 184.7316 & 0.126064852 & 1.865976 & 0.802466252 & 1.28 & 1.423126275 \\
GxL & 99 & 262.2779 & 0.178984093 & 2.649272 & 1.139323862 & 1.28 & 1.423126275 \\
Pool Error & 396 & 920.8195 & 0.628387058 & 2.325302 & & & \\
Total & 599 & 1465.37 & & & & & \\
\hline
\end{tabular}

F-Cal $\geq$ F-Tab 0.01= Highly Significant, F-Cal $\geq$ F-Tab 0.05= Significant and F-Cal $<$ F-Tab 0.05= Non-significant 
Table S5. Analysis of variance (RCB design) of Number of Spikelets Spike $e^{-1}$ for 100 selected accessions with three replications across two locations for environmental interactions

\begin{tabular}{c|c|c|c|c|c|c|c}
\hline SOV & DF & SS & SS\% & MS & F-Cal & F-Tab @ 0.05 & F-Tab @ 0.01 \\
\hline Locations & 1 & 62.08167 & 0.010075 & 62.08167 & 0.44953597 & 7.71 & 21.19768958 \\
Reps w/n Loc & 4 & 552.4067 & & 138.1017 & & & \\
Genotypes & 99 & 904.965 & 0.146867 & 9.141061 & 0.972838307 & 1.28 & 1.423126275 \\
GxL & 99 & 921.4183 & 0.149537 & 9.307256 & 0.990525658 & 1.28 & 1.423126275 \\
Pool Error & 396 & 3720.927 & 0.60387 & 9.396279 & & & \\
Total & 599 & 6161.798 & & & & & \\
\hline
\end{tabular}

F-Cal $\geq$ F-Tab $0.01=$ Highly Significant, F-Cal $\geq$ F-Tab $0.05=$ Significant and F-Cal $<$ F-Tab $0.05=$ Non-significant

Table S6. Analysis of variance (RCB design) of seeds spike ${ }^{-1}$ for 100 selected accessions with three replications across two locations for environmental interactions

\begin{tabular}{c|c|c|c|c|c|c|c}
\hline SOV & DF & SS & SS\% & MS & F-Cal & F-Tab @ 0.05 & F-Tab @ 0.01 \\
\hline Locations & 1 & 0.06 & $8.0795 E-07$ & 0.06 & $2.1501 \mathrm{E}-05$ & 7.71 & 21.19768958 \\
Reps w/n Loc & 4 & 11162.25 & & 2790.563 & & & \\
Genotypes & 99 & 13507.33 & 0.18188918 & 136.4377 & 1.3613606 & 1.28 & 1.4231262 \\
GxL & 99 & 9903.94 & 0.133366 & 100.0398 & 0.9981861 & 1.28 & 1.4231262 \\
Pool Error & 396 & 39687.75 & 0.53444 & 100.2216 & & & \\
Total & 599 & 74261.33 & & & & & \\
\hline
\end{tabular}

F-Cal $\geq$ F-Tab 0.01= Highly Significant, F-Cal $\geq$ F-Tab $0.05=$ Significant and F-Cal $<$ F-Tab $0.05=$ Non-significant

Table S7. Analysis of variance (RCB design) of spike plant ${ }^{-1}$ for 100 selected accessions with three replications across two locations for environmental interactions

\begin{tabular}{c|c|c|c|c|c|c|c}
\hline SOV & DF & SS & SS\% & MS & F-Cal & F-Tab @ 0.05 & F-Tab @ 0.01 \\
\hline Locations & 1 & 45.375 & 0.031941 & 45.375 & 1.50447612 & 7.71 & 21.19769 \\
Reps w/n Loc & 4 & 120.64 & & 30.16 & & & \\
Genotypes & 99 & 226.4183 & 0.159384 & 2.287054 & 1.052260193 & 1.28 & 1.423126275 \\
GxL & 99 & 167.4583 & 0.11788 & 1.6914 & 0.77824854 & 1.28 & 1.423126 \\
Pool Error & 396 & 860.6933 & 0.605872 & 2.1734 & & & \\
Total & 599 & 1420.585 & & & & & \\
\hline
\end{tabular}

F-Cal $\geq$ F-Tab 0.01= Highly Significant, F-Cal $\geq$ F-Tab $0.05=$ Significant and F-Cal $<$ F-Tab $0.05=$ Non-significant

Table S8. Analysis of variance (RCB design) of seeds plant $^{-1}$ for 100 selected accessions with three replications across two locations for environmental interactions

\begin{tabular}{c|c|c|c|c|c|c|c}
\hline SOV & DF & SS & SS\% & MS & F-Cal & F-Tab @ 0.05 & F-Tab @ 0.01 \\
\hline Locations & 1 & 16727.0 & 0.00321829 & 16727.04 & 0.85684897 & 7.71 & 21.19768958 \\
Reps w/n Loc & 4 & 78086.2 & & 19521.57 & & & \\
Genotypes & 99 & 838221 & 0.16127461 & 8466.884 & 0.95298555 & 1.28 & 1.423126275 \\
GxL & 99 & 746147 & 0.14355956 & 7536.848 & 0.84830581 & 1.28 & 1.423126275 \\
Pool Error & 396 & 3518297 & 0.67692364 & 8884.588 & & & \\
Total & 599 & 5197479 & & & & & \\
\hline
\end{tabular}

F-Cal $\geq$ F-Tab 0.01= Highly Significant, F-Cal $\geq$ F-Tab $0.05=$ Significant and F-Cal $<$ F-Tab $0.05=$ Non-significant 
Table S9. Combined morphological data for 13 parameters used for PCA

\begin{tabular}{|c|c|c|c|c|c|c|c|c|c|c|c|c|c|c|}
\hline S.No & Acc. & Germination & $\begin{array}{c}1^{\text {st }} \text { leaf } \\
\text { (days after } \\
\text { germination) }\end{array}$ & $\begin{array}{l}2^{\text {st }} \text { leaf } \\
\text { (days) }\end{array}$ & $\begin{array}{c}\text { 3rd leaf } \\
\text { (days) }\end{array}$ & $\begin{array}{c}\text { Booting } \\
\text { (days) }\end{array}$ & $\begin{array}{l}\text { Half open } \\
\text { (days) }\end{array}$ & $\begin{array}{l}\text { Heading } \\
\text { (days) }\end{array}$ & $\begin{array}{c}\text { Fertilization } \\
\text { (days) }\end{array}$ & $\begin{array}{c}\text { Leaf length } \\
(\mathrm{cm})\end{array}$ & $\begin{array}{c}\text { Width } \\
(\mathbf{c m})\end{array}$ & $\begin{array}{c}\text { Plant height } \\
(\mathrm{cm})\end{array}$ & $\begin{array}{c}\text { Peduncle } \\
(\mathrm{cm})\end{array}$ & $\begin{array}{c}\text { No of seed / } \\
\text { spike }\end{array}$ \\
\hline 1 & 11123 & 12.33 & 7.33 & 6.33 & 4.33 & 118.00 & 127.67 & 131.00 & 136.00 & 21.00 & 1.43 & 75 & 24.00 & 33.00 \\
\hline 2 & 11126 & 11.67 & 7.33 & 6.33 & 4.33 & 115.50 & 124.33 & 129.00 & 134.00 & 20.33 & 1.43 & 70 & 26.33 & 42.00 \\
\hline 3 & 11144 & 13.33 & 8.00 & 7.00 & 4.67 & 125.00 & 128.33 & 132.67 & 140.33 & 17.33 & 1.37 & 90 & 28.00 & 49.00 \\
\hline 4 & 11145 & 11.33 & 6.33 & 6.33 & 4.67 & 109.00 & 124.33 & 128.33 & 136.67 & 22.00 & 1.40 & 68 & 22.33 & 35.00 \\
\hline 5 & 11152 & 11.00 & 6.33 & 6.33 & 4.33 & 113.50 & 121.33 & 125.00 & 130.33 & 18.00 & 1.43 & 75 & 27.00 & 30.00 \\
\hline 6 & 11154 & 16.00 & 8.67 & 7.67 & 4.67 & 97.00 & 107.33 & 111.67 & 118.33 & 20.33 & 1.67 & 69 & 25.67 & 46.00 \\
\hline 7 & 11155 & 10.00 & 7.00 & 6.00 & 4.33 & 91.00 & 105.67 & 110.67 & 117.67 & 21.33 & 1.27 & 103 & 25.00 & 23.00 \\
\hline 8 & 11160 & 12.33 & 7.67 & 6.67 & 4.33 & 115.50 & 128.33 & 133.00 & 140.00 & 21.33 & 1.27 & 79 & 28.33 & 42.00 \\
\hline 9 & 11161 & 7.00 & 6.67 & 6.00 & 4.33 & 109.00 & 120.33 & 124.67 & 131.00 & 19.33 & 1.30 & 77 & 27.67 & 34.00 \\
\hline 10 & 11162 & 12.00 & 7.00 & 6.33 & 4.00 & 113.00 & 123.33 & 128.00 & 134.67 & 21.00 & 1.37 & 98 & 26.00 & 23.00 \\
\hline 11 & 11163 & 12.67 & 7.67 & 6.67 & 4.33 & 111.67 & 120.67 & 125.67 & 134.00 & 21.00 & 1.40 & 75 & 27.67 & 32.00 \\
\hline 12 & 11164 & 12.67 & 7.33 & 6.33 & 4.33 & 117.00 & 126.00 & 130.00 & 135.67 & 18.67 & 1.43 & 72 & 24.00 & 30.00 \\
\hline 13 & 11166 & 12.00 & 7.00 & 6.67 & 4.00 & 117.33 & 125.00 & 128.67 & 136.00 & 20.67 & 1.40 & 78 & 29.67 & 46.00 \\
\hline 14 & 11168 & 13.33 & 7.33 & 6.67 & 4.33 & 114.67 & 125.33 & 130.33 & 138.00 & 19.67 & 1.30 & 105 & 32.33 & 65.00 \\
\hline 15 & 11170 & 12.67 & 7.33 & 7.00 & 4.33 & 125.33 & 132.33 & 136.00 & 143.67 & 16.33 & 1.40 & 75 & 28.67 & 48.00 \\
\hline 16 & 11171 & 13.33 & 7.33 & 6.67 & 4.33 & 111.67 & 121.00 & 125.00 & 129.67 & 21.67 & 1.43 & 68 & 26.67 & 33.00 \\
\hline 17 & 11173 & 13.33 & 7.67 & 6.67 & 4.67 & 114.33 & 122.33 & 127.00 & 134.67 & 16.00 & 1.47 & 68 & 26.67 & 44.00 \\
\hline 18 & 11174 & 13.33 & 7.00 & 6.33 & 4.33 & 114.00 & 122.00 & 127.33 & 135.00 & 19.00 & 1.63 & 65 & 24.67 & 38.00 \\
\hline 19 & 11177 & 14.67 & 7.00 & 7.00 & 4.67 & 114.33 & 122.33 & 127.33 & 133.33 & 17.67 & 1.43 & 72 & 27.33 & 23.00 \\
\hline 20 & 11178 & 14.67 & 6.67 & 6.67 & 4.33 & 113.33 & 121.33 & 125.33 & 131.33 & 19.00 & 1.37 & 109 & 21.67 & 43.00 \\
\hline 21 & 11179 & 13.00 & 6.33 & 7.00 & 4.67 & 110.33 & 118.67 & 123.67 & 130.00 & 20.00 & 1.17 & 75 & 25.00 & 37.00 \\
\hline 22 & 11181 & 11.00 & 6.33 & 7.00 & 4.67 & 114.00 & 122.33 & 126.33 & 132.00 & 23.67 & 1.33 & 67 & 26.33 & 46.00 \\
\hline 23 & 11183 & 13.67 & 6.33 & 6.67 & 4.33 & 117.67 & 125.00 & 129.00 & 136.00 & 22.00 & 1.63 & 73 & 32.00 & 31.00 \\
\hline 24 & 11184 & 16.00 & 6.67 & 7.33 & 5.00 & 117.67 & 126.33 & 130.00 & 136.33 & 24.67 & 1.53 & 108 & 25.00 & 22.00 \\
\hline 25 & 11185 & 14.33 & 7.67 & 6.67 & 4.67 & 116.33 & 125.33 & 129.67 & 136.67 & 23.33 & 1.43 & 85 & 30.67 & 33.00 \\
\hline 26 & 11186 & 12.33 & 7.67 & 6.67 & 4.67 & 119.33 & 127.67 & 132.00 & 138.33 & 23.33 & 1.33 & 96 & 28.67 & 19.00 \\
\hline 27 & 11187 & 14.67 & 7.33 & 7.00 & 5.00 & 114.00 & 121.67 & 127.00 & 131.67 & 19.67 & 1.37 & 97 & 32.33 & 21.00 \\
\hline 28 & 11188 & 12.00 & 7.00 & 6.00 & 4.00 & 110.67 & 118.00 & 122.33 & 128.00 & 20.33 & 1.40 & 92 & 34.33 & 34.00 \\
\hline 29 & 11189 & 12.67 & 7.00 & 6.33 & 4.33 & 101.00 & 109.67 & 114.00 & 121.00 & 22.67 & 1.33 & 89 & 32.00 & 23.00 \\
\hline 30 & 11190 & 11.33 & 7.00 & 6.00 & 4.00 & 98.00 & 108.67 & 113.00 & 121.33 & 23.67 & 1.40 & 98 & 28.00 & 21.00 \\
\hline 31 & 11192 & 12.33 & 7.00 & 6.00 & 4.00 & 115.00 & 125.67 & 129.67 & 135.00 & 19.67 & 1.40 & 84 & 29.00 & 26.00 \\
\hline
\end{tabular}

APPLIED ECOLOGY AND ENVIRONMENTAL RESEARCH 18(6):8091-8118.

http://www aloki hu • ISSN 15891623 (Print) • ISSN1785 0037 (Online)

DOI: http://dx.doi.org/10.15666/aeer/1806_80918118

(c) 2020, ALÖKI Kft., Budapest, Hungary 


\begin{tabular}{|c|c|c|c|c|c|c|c|c|c|c|c|c|c|c|}
\hline 32 & 11193 & 13.33 & 7.33 & 7.00 & 5.00 & 110.00 & 122.67 & 127.00 & 134.00 & 26.33 & 1.50 & 69 & 28.33 & 24.00 \\
\hline 33 & 11194 & 13.67 & 7.67 & 6.67 & 4.33 & 132.67 & 140.00 & 143.67 & 148.67 & 27.00 & 1.30 & 85 & 27.67 & 31.00 \\
\hline 34 & 11195 & 13.00 & 7.33 & 6.33 & 4.33 & 118.00 & 127.33 & 131.00 & 138.67 & 26.33 & 1.53 & 87 & 27.33 & 38.00 \\
\hline 35 & 11197 & 13.67 & 8.00 & 6.00 & 5.00 & 128.67 & 134.00 & 138.00 & 142.33 & 26.67 & 1.27 & 78 & 45.67 & 33.00 \\
\hline 36 & 11198 & 12.67 & 7.33 & 6.33 & 4.33 & 132.67 & 138.33 & 142.67 & 146.67 & 27.33 & 1.33 & 103 & 32.00 & 45.00 \\
\hline 37 & 11200 & 13.67 & 7.67 & 6.67 & 4.67 & 118.00 & 125.33 & 129.33 & 133.00 & 25.67 & 1.33 & 75 & 28.33 & 19.00 \\
\hline 38 & 11202 & 12.33 & 7.33 & 6.33 & 4.33 & 128.67 & 135.67 & 139.67 & 144.00 & 23.67 & 1.50 & 81 & 27.00 & 50.00 \\
\hline 39 & 11205 & 11.67 & 7.33 & 6.33 & 4.33 & 132.33 & 140.00 & 143.67 & 148.67 & 24.33 & 1.43 & 74 & 31.00 & 31.00 \\
\hline 40 & 11207 & 14.33 & 8.00 & 7.00 & 5.00 & 127.33 & 134.67 & 139.00 & 143.67 & 25.00 & 1.43 & 88 & 32.67 & 45.00 \\
\hline 41 & 11208 & 12.67 & 7.67 & 6.67 & 4.67 & 127.00 & 134.67 & 138.33 & 144.67 & 22.00 & 1.30 & 83 & 34.33 & 39.00 \\
\hline 42 & 11209 & 11.33 & 7.67 & 6.67 & 4.67 & 122.67 & 129.33 & 133.33 & 138.33 & 21.33 & 1.30 & 86 & 24.00 & 32.00 \\
\hline 43 & 11210 & 10.67 & 7.00 & 6.00 & 4.67 & 125.67 & 130.00 & 133.67 & 138.67 & 21.33 & 1.10 & 78 & 22.33 & 40.00 \\
\hline 44 & 11211 & 12.00 & 7.67 & 6.67 & 4.67 & 127.33 & 135.67 & 140.00 & 145.67 & 26.00 & 1.37 & 75 & 22.67 & 25.00 \\
\hline 45 & 11214 & 12.00 & 7.33 & 6.33 & 4.33 & 118.67 & 128.67 & 133.33 & 140.33 & 24.33 & 1.27 & 75 & 22.33 & 39.00 \\
\hline 46 & 11215 & 7.00 & 7.00 & 6.00 & 4.67 & 113.33 & 122.33 & 127.33 & 133.00 & 21.00 & 1.30 & 91 & 35.67 & 38.00 \\
\hline 47 & 11216 & 11.33 & 7.67 & 6.67 & 4.67 & 88.67 & 98.33 & 103.00 & 109.33 & 22.67 & 1.40 & 77 & 33.67 & 43.00 \\
\hline 48 & 11217 & 8.00 & 7.00 & 6.00 & 4.67 & 128.00 & 135.00 & 138.67 & 143.67 & 22.67 & 1.53 & 88 & 28.67 & 47.00 \\
\hline 49 & 11218 & 5.67 & 6.33 & 5.33 & 4.67 & 113.00 & 122.67 & 127.33 & 133.00 & 23.00 & 1.67 & 83 & 30.00 & 39.00 \\
\hline 50 & 11221 & 11.00 & 7.67 & 6.67 & 4.67 & 126.33 & 134.67 & 139.67 & 145.33 & 23.67 & 1.43 & 86 & 29.00 & 34.00 \\
\hline 51 & 11222 & 10.33 & 6.67 & 5.67 & 4.33 & 129.33 & 131.67 & 136.33 & 142.00 & 23.33 & 1.37 & 82 & 27.67 & 39.00 \\
\hline 52 & 11223 & 9.00 & 6.67 & 5.67 & 4.33 & 111.00 & 122.67 & 127.00 & 133.33 & 26.00 & 1.40 & 96 & 36.33 & 44.00 \\
\hline 53 & 11224 & 10.33 & 7.00 & 6.00 & 4.67 & 125.67 & 133.00 & 136.67 & 141.33 & 18.33 & 1.27 & 86 & 27.33 & 38.00 \\
\hline 54 & 11225 & 9.67 & 7.00 & 6.00 & 4.67 & 114.33 & 124.33 & 128.00 & 133.00 & 23.00 & 1.20 & 84 & 30.33 & 34.00 \\
\hline 55 & 11226 & 10.00 & 7.00 & 6.00 & 4.67 & 112.33 & 122.00 & 125.67 & 131.67 & 22.33 & 1.37 & 81 & 31.00 & 56.00 \\
\hline 56 & 11227 & 13.00 & 7.67 & 6.67 & 4.67 & 110.00 & 119.67 & 124.00 & 128.67 & 21.00 & 1.50 & 89 & 26.33 & 35.00 \\
\hline 57 & 11228 & 11.67 & 6.67 & 6.67 & 4.67 & 114.00 & 125.00 & 129.33 & 137.00 & 22.67 & 1.50 & 73 & 25.00 & 41.00 \\
\hline 58 & 11229 & 14.33 & 8.00 & 7.00 & 5.00 & 115.00 & 125.33 & 129.67 & 135.33 & 24.00 & 1.43 & 86 & 31.33 & 42.00 \\
\hline 59 & 11231 & 13.33 & 7.00 & 6.67 & 4.67 & 119.67 & 128.00 & 132.00 & 139.33 & 23.00 & 1.33 & 55 & 31.33 & 52.00 \\
\hline 60 & 11233 & 13.67 & 6.67 & 7.33 & 5.33 & 117.33 & 125.00 & 129.33 & 135.33 & 24.67 & 1.70 & 91 & 33.33 & 52.00 \\
\hline 61 & 11236 & 14.67 & 8.00 & 7.00 & 5.00 & 114.00 & 123.33 & 129.33 & 136.00 & 20.00 & 1.47 & 81 & 28.33 & 53.00 \\
\hline 62 & 11237 & 10.67 & 7.00 & 6.00 & 4.00 & 113.33 & 121.33 & 126.67 & 132.00 & 22.33 & 1.53 & 85 & 30.00 & 44.00 \\
\hline 63 & 11239 & 13.33 & 7.67 & 6.67 & 4.67 & 119.00 & 127.33 & 132.67 & 140.00 & 30.33 & 1.60 & 90 & 32.00 & 34.00 \\
\hline 64 & 11240 & 11.67 & 7.67 & 6.67 & 4.67 & 118.00 & 126.00 & 131.33 & 137.67 & 21.67 & 1.30 & 93 & 20.33 & 32.00 \\
\hline 65 & 11242 & 17.67 & 7.67 & 6.67 & 4.67 & 109.67 & 120.67 & 124.67 & 132.67 & 20.67 & 1.33 & 86 & 28.00 & 38.00 \\
\hline 66 & 11243 & 11.33 & 7.33 & 6.33 & 4.33 & 113.00 & 123.67 & 129.00 & 136.00 & 22.33 & 1.60 & 85 & 26.67 & 29.00 \\
\hline
\end{tabular}

APPLIED ECOLOGY AND ENVIRONMENTAL RESEARCH 18(6):8091-8118.

http://www.aloki.hu • ISSN 15891623 (Print) • ISSN1785 0037 (Online)

DOI: http://dx.doi.org/10.15666/aeer/1806_80918118

(c) 2020, ALÖKI Kft., Budapest, Hungary 


\begin{tabular}{|c|c|c|c|c|c|c|c|c|c|c|c|c|c|c|}
\hline 67 & 11244 & 11.00 & 7.33 & 6.33 & 4.33 & 111.67 & 120.33 & 124.67 & 130.33 & 20.67 & 1.37 & 84 & 25.33 & 27.00 \\
\hline 68 & 11246 & 11.00 & 7.00 & 6.00 & 4.00 & 115.67 & 124.00 & 128.00 & 133.33 & 22.00 & 1.27 & 84 & 30.67 & 25.00 \\
\hline 69 & 11248 & 12.67 & 7.33 & 6.33 & 4.33 & 93.33 & 104.33 & 109.33 & 117.00 & 21.67 & 1.33 & 72 & 22.67 & 24.00 \\
\hline 70 & 11249 & 12.33 & 7.33 & 6.33 & 4.33 & 114.33 & 125.67 & 129.67 & 135.33 & 22.67 & 1.57 & 77 & 29.33 & 21.00 \\
\hline 71 & 11250 & 11.33 & 7.33 & 6.33 & 4.33 & 115.00 & 124.67 & 129.00 & 136.00 & 28.67 & 1.63 & 96 & 36.00 & 45.00 \\
\hline 72 & 11252 & 12.00 & 7.33 & 6.33 & 4.33 & 112.67 & 122.33 & 127.33 & 133.67 & 22.67 & 1.40 & 73 & 24.33 & 34.00 \\
\hline 73 & 11253 & 16.33 & 8.33 & 5.33 & 5.33 & 111.67 & 121.33 & 125.33 & 133.00 & 19.00 & 1.20 & 63 & 22.00 & 22.00 \\
\hline 74 & 11255 & 18.00 & 9.00 & 5.33 & 5.33 & 112.67 & 119.33 & 123.33 & 130.67 & 21.67 & 1.60 & 76 & 31.00 & 39.00 \\
\hline 75 & 11256 & 13.67 & 7.00 & 5.67 & 4.67 & 102.67 & 113.33 & 117.00 & 126.00 & 22.67 & 1.50 & 72 & 21.33 & 36.00 \\
\hline 76 & 11259 & 11.67 & 7.67 & 6.67 & 4.67 & 114.67 & 123.33 & 127.67 & 137.00 & 22.00 & 1.33 & 72 & 25.67 & 50.00 \\
\hline 77 & 11261 & 11.33 & 7.33 & 6.33 & 4.33 & 124.33 & 132.67 & 137.33 & 142.67 & 21.33 & 1.37 & 93 & 32.33 & 19.00 \\
\hline 78 & 11265 & 12.00 & 8.00 & 6.00 & 5.00 & 118.67 & 128.33 & 132.00 & 136.67 & 21.33 & 1.23 & 72 & 29.00 & 26.00 \\
\hline 79 & 11272 & 18.33 & 9.00 & 5.00 & 6.00 & 117.00 & 124.33 & 128.33 & 136.67 & 21.33 & 1.17 & 76 & 27.67 & 46.00 \\
\hline 80 & 11274 & 12.33 & 7.67 & 5.67 & 4.67 & 93.67 & 106.00 & 109.67 & 119.33 & 26.00 & 1.43 & 85 & 29.33 & 25.00 \\
\hline 81 & 11275 & 12.33 & 7.67 & 5.67 & 4.67 & 107.33 & 116.67 & 120.67 & 126.33 & 21.67 & 1.37 & 87 & 27.33 & 33.00 \\
\hline 82 & 11278 & 13.33 & 8.00 & 6.00 & 5.00 & 107.67 & 117.33 & 122.67 & 129.67 & 19.67 & 1.40 & 94 & 30.00 & 35.00 \\
\hline 83 & 11288 & 8.67 & 7.33 & 5.33 & 5.00 & 104.00 & 114.33 & 119.00 & 126.67 & 25.33 & 1.47 & 72 & 23.00 & 34.00 \\
\hline 84 & 11290 & 12.00 & 8.00 & 6.00 & 5.00 & 113.33 & 121.33 & 125.33 & 129.00 & 17.33 & 1.40 & 72 & 31.00 & 32.00 \\
\hline 85 & 11292 & 12.00 & 8.00 & 5.33 & 5.00 & 114.33 & 124.00 & 128.00 & 135.33 & 19.33 & 1.33 & 72 & 23.67 & 22.00 \\
\hline 86 & 11293 & 12.33 & 7.33 & 6.33 & 4.33 & 114.67 & 123.33 & 127.00 & 134.00 & 17.33 & 1.30 & 77 & 29.33 & 16.00 \\
\hline 87 & 11294 & 11.33 & 7.33 & 6.00 & 4.33 & 116.00 & 125.33 & 129.00 & 133.67 & 19.33 & 1.57 & 80 & 25.33 & 23.00 \\
\hline 88 & 11295 & 10.67 & 7.67 & 5.67 & 4.67 & 113.33 & 124.67 & 129.33 & 136.67 & 19.33 & 1.60 & 96 & 28.00 & 19.00 \\
\hline 89 & 11296 & 11.00 & 7.67 & 5.67 & 4.67 & 116.33 & 125.33 & 130.00 & 136.00 & 19.33 & 1.40 & 72 & 27.33 & 9.00 \\
\hline 90 & 11297 & 10.33 & 7.67 & 5.67 & 4.67 & 112.33 & 121.67 & 125.33 & 130.00 & 20.00 & 1.53 & 80 & 25.00 & 35.00 \\
\hline 91 & 11299 & 11.67 & 7.67 & 5.67 & 4.67 & 101.00 & 111.67 & 115.67 & 122.67 & 16.67 & 1.33 & 78 & 28.33 & 39.00 \\
\hline 92 & 11304 & 12.67 & 7.67 & 5.67 & 4.67 & 104.67 & 115.00 & 120.00 & 127.67 & 19.67 & 1.37 & 79 & 25.33 & 31.00 \\
\hline 93 & 11317 & 15.33 & 8.00 & 6.33 & 5.00 & 107.67 & 117.00 & 121.67 & 129.00 & 22.33 & 1.50 & 82 & 27.33 & 28.00 \\
\hline 94 & 11553 & 12.33 & 7.67 & 6.00 & 4.67 & 111.00 & 122.67 & 127.33 & 134.67 & 21.00 & 1.33 & 86 & 32.33 & 29.00 \\
\hline 95 & 11558 & 18.00 & 9.00 & 5.67 & 5.00 & 110.33 & 120.33 & 125.00 & 132.67 & 20.33 & 1.37 & 76 & 23.33 & 24.00 \\
\hline 96 & 12087 & 12.00 & 7.67 & 6.67 & 4.67 & 108.00 & 119.33 & 123.33 & 129.00 & 22.00 & 1.43 & 82 & 31.33 & 28.00 \\
\hline 97 & 12100 & 13.67 & 8.00 & 7.00 & 5.00 & 114.33 & 122.00 & 126.67 & 132.67 & 20.00 & 1.90 & 81 & 26.67 & 44.00 \\
\hline 98 & 12231 & 12.00 & 7.33 & 6.33 & 4.33 & 116.00 & 124.33 & 128.67 & 133.67 & 20.33 & 1.43 & 82 & 28.00 & 25.00 \\
\hline 99 & 18668 & 13.00 & 7.67 & 6.67 & 4.67 & 117.00 & 123.67 & 127.33 & 133.00 & 23.67 & 1.50 & 87 & 28.67 & 26.00 \\
\hline 100 & 24740 & 13.33 & 7.67 & 7.00 & 4.67 & 118.00 & 126.67 & 130.33 & 136.67 & 21.00 & 1.37 & 101 & 25.67 & 13.00 \\
\hline
\end{tabular}

APPLIED ECOLOGY AND ENVIRONMENTAL RESEARCH 18(6):8091-8118.

http://www.aloki.hu • ISSN 15891623 (Print) • ISSN1785 0037 (Online)

DOI: http://dx.doi.org/10.15666/aeer/1806_80918118

(c) 2020, ALÖKI Kft., Budapest, Hungary 
Table S10. PCR confirmation of 22 SSR along with band size for indigenous germplasm

\begin{tabular}{|c|c|c|c|c|c|c|c|c|c|c|c|c|}
\hline $\begin{array}{l}\text { Acc } \\
\text { No. }\end{array}$ & $\begin{array}{c}\text { XGWM35 } \\
\text { 225bp }\end{array}$ & $\begin{array}{c}\text { XGWM35 } \\
\text { 200bp }\end{array}$ & $\begin{array}{c}\text { WMC419 } \\
\text { 200bp }\end{array}$ & $\begin{array}{c}\text { XGWM120 } \\
\text { 150bp }\end{array}$ & $\begin{array}{c}\text { GWM174 } \\
220 b p\end{array}$ & $\begin{array}{c}\text { XGWM140 } \\
\text { 120bp }\end{array}$ & $\begin{array}{c}\text { XWMC170 } \\
200 b p\end{array}$ & $\begin{array}{c}\text { XWMC405 } \\
220 b p\end{array}$ & $\begin{array}{c}\text { XWMC348 } \\
\text { 130bp }\end{array}$ & $\begin{array}{c}\text { XWMC407 } \\
\text { 120bp }\end{array}$ & $\begin{array}{c}\text { GWM } 148 \\
\text { 190bp }\end{array}$ & $\begin{array}{c}\text { GWM148 } \\
\text { 200bp }\end{array}$ \\
\hline 1 & 0 & 0 & 1 & 0 & 0 & 1 & 0 & 0 & 0 & 1 & 1 & 0 \\
\hline 2 & 0 & 0 & 1 & 0 & 0 & 1 & 0 & 1 & 0 & 1 & 1 & 0 \\
\hline 3 & 0 & 0 & 1 & 0 & 0 & 1 & 1 & 1 & 0 & 1 & 1 & 0 \\
\hline 4 & 0 & 0 & 1 & 1 & 0 & 1 & 1 & 0 & 0 & 1 & 1 & 0 \\
\hline 5 & 0 & 0 & 1 & 0 & 0 & 1 & 0 & 0 & 0 & 1 & 1 & 0 \\
\hline 6 & 1 & 0 & 1 & 0 & 0 & 1 & 1 & 1 & 0 & 0 & 1 & 0 \\
\hline 7 & 1 & 0 & 0 & 0 & 0 & 0 & 0 & 1 & 0 & 0 & 1 & 0 \\
\hline 8 & 1 & 0 & 1 & 1 & 0 & 1 & 0 & 1 & 0 & 1 & 1 & 0 \\
\hline 9 & 0 & 0 & 0 & 1 & 0 & 1 & 1 & 0 & 0 & 0 & 1 & 0 \\
\hline 10 & 0 & 0 & 1 & 1 & 0 & 0 & 1 & 1 & 0 & 0 & 1 & 0 \\
\hline 11 & 1 & 0 & 1 & 1 & 0 & 1 & 1 & 1 & 0 & 1 & 1 & 0 \\
\hline 12 & 0 & 0 & 1 & 0 & 0 & 1 & 0 & 1 & 0 & 1 & 1 & 0 \\
\hline 13 & 0 & 0 & 1 & 0 & 0 & 1 & 0 & 0 & 0 & 1 & 1 & 0 \\
\hline 14 & 0 & 0 & 1 & 0 & 0 & 1 & 0 & 1 & 0 & 1 & 1 & 0 \\
\hline 15 & 0 & 0 & 1 & 0 & 0 & 1 & 0 & 1 & 0 & 1 & 1 & 0 \\
\hline 16 & 0 & 0 & 0 & 0 & 0 & 0 & 0 & 1 & 0 & 1 & 1 & 0 \\
\hline 17 & 0 & 0 & 1 & 0 & 0 & 1 & 0 & 0 & 0 & 0 & 1 & 0 \\
\hline 18 & 0 & 0 & 1 & 0 & 0 & 1 & 0 & 0 & 1 & 1 & 1 & 0 \\
\hline 19 & 0 & 0 & 0 & 0 & 0 & 0 & 0 & 0 & 0 & 1 & 1 & 0 \\
\hline 20 & 0 & 0 & 1 & 1 & 0 & 0 & 1 & 1 & 1 & 0 & 1 & 0 \\
\hline 21 & 0 & 0 & 1 & 0 & 0 & 0 & 0 & 1 & 1 & 0 & 0 & 0 \\
\hline 22 & 0 & 0 & 1 & 1 & 0 & 0 & 1 & 1 & 0 & 0 & 1 & 0 \\
\hline 23 & 0 & 0 & 0 & 0 & 0 & 0 & 1 & 1 & 1 & 0 & 1 & 0 \\
\hline 24 & 0 & 0 & 1 & 0 & 0 & 0 & 1 & 1 & 0 & 0 & 1 & 0 \\
\hline 25 & 0 & 0 & 1 & 1 & 0 & 0 & 0 & 1 & 0 & 0 & 1 & 0 \\
\hline 26 & 0 & 0 & 1 & 0 & 0 & 0 & 1 & 1 & 1 & 0 & 1 & 0 \\
\hline 27 & 0 & 0 & 0 & 0 & 0 & 0 & 1 & 1 & 1 & 1 & 1 & 0 \\
\hline 28 & 0 & 0 & 0 & 1 & 0 & 0 & 1 & 0 & 1 & 1 & 1 & 0 \\
\hline 29 & 0 & 0 & 1 & 1 & 0 & 0 & 1 & 1 & 1 & 1 & 1 & 0 \\
\hline 30 & 0 & 0 & 0 & 0 & 0 & 0 & 1 & 1 & 1 & 0 & 1 & 0 \\
\hline 31 & 0 & 0 & 0 & 0 & 0 & 1 & 1 & 1 & 1 & 0 & 1 & 0 \\
\hline 32 & 0 & 0 & 0 & 1 & 0 & 0 & 1 & 1 & 1 & 0 & 1 & 0 \\
\hline 33 & 0 & 0 & 0 & 0 & 0 & 0 & 1 & 1 & 0 & 0 & 0 & 0 \\
\hline
\end{tabular}


Khattak et al.: Investigating the allelic variation of loci controlling rust resistance genes in wheat (Triticum aestivum L.) land races by SSR marker -8111 -

\begin{tabular}{|c|c|c|c|c|c|c|c|c|c|c|c|c|}
\hline 34 & 0 & 0 & 1 & 0 & 0 & 0 & 1 & 1 & 1 & 0 & 0 & 0 \\
\hline 35 & 0 & 0 & 0 & 0 & 0 & 0 & 0 & 1 & 1 & 0 & 0 & 0 \\
\hline 36 & 0 & 0 & 1 & 1 & 0 & 0 & 0 & 1 & 0 & 0 & 0 & 0 \\
\hline 37 & 0 & 0 & 0 & 0 & 0 & 1 & 1 & 1 & 0 & 0 & 1 & 0 \\
\hline 38 & 0 & 0 & 1 & 0 & 0 & 1 & 1 & 1 & 0 & 1 & 1 & 0 \\
\hline 39 & 0 & 0 & 0 & 0 & 0 & 0 & 0 & 1 & 0 & 1 & 0 & 0 \\
\hline 40 & 0 & 0 & 0 & 0 & 0 & 1 & 0 & 1 & 1 & 1 & 0 & 1 \\
\hline 41 & 0 & 0 & 1 & 1 & 0 & 1 & 0 & 1 & 0 & 1 & 0 & 1 \\
\hline 42 & 0 & 0 & 0 & 1 & 0 & 1 & 1 & 1 & 1 & 1 & 0 & 1 \\
\hline 43 & 0 & 0 & 0 & 1 & 0 & 0 & 0 & 1 & 0 & 1 & 0 & 1 \\
\hline 44 & 0 & 0 & 0 & 1 & 0 & 0 & 0 & 1 & 0 & 0 & 0 & 0 \\
\hline 45 & 0 & 0 & 0 & 1 & 0 & 1 & 1 & 0 & 1 & 1 & 0 & 1 \\
\hline 46 & 0 & 0 & 1 & 1 & 0 & 0 & 0 & 1 & 1 & 1 & 0 & 1 \\
\hline 47 & 0 & 0 & 0 & 0 & 0 & 1 & 1 & 1 & 1 & 0 & 0 & 1 \\
\hline 48 & 1 & 0 & 0 & 1 & 1 & 0 & 1 & 1 & 1 & 0 & 0 & 0 \\
\hline 49 & 0 & 0 & 1 & 1 & 0 & 1 & 1 & 1 & 1 & 0 & 0 & 1 \\
\hline 50 & 1 & 0 & 0 & 1 & 0 & 0 & 1 & 1 & 1 & 0 & 0 & 0 \\
\hline 51 & 0 & 0 & 0 & 1 & 0 & 1 & 1 & 0 & 1 & 0 & 0 & 1 \\
\hline 52 & 0 & 0 & 0 & 1 & 0 & 1 & 1 & 1 & 0 & 0 & 0 & 1 \\
\hline 53 & 0 & 0 & 1 & 1 & 0 & 1 & 0 & 1 & 1 & 0 & 0 & 1 \\
\hline 54 & 0 & 0 & 0 & 1 & 0 & 1 & 1 & 1 & 1 & 0 & 0 & 1 \\
\hline 55 & 0 & 0 & 1 & 1 & 0 & 0 & 0 & 1 & 0 & 0 & 0 & 1 \\
\hline 56 & 0 & 0 & 1 & 1 & 0 & 0 & 1 & 0 & 0 & 1 & 1 & 0 \\
\hline 57 & 0 & 0 & 0 & 0 & 0 & 0 & 1 & 1 & 0 & 1 & 1 & 0 \\
\hline 58 & 0 & 0 & 1 & 0 & 0 & 1 & 1 & 1 & 0 & 0 & 1 & 0 \\
\hline 59 & 0 & 0 & 1 & 1 & 0 & 1 & 1 & 1 & 0 & 0 & 1 & 0 \\
\hline 60 & 0 & 0 & 1 & 1 & 0 & 0 & 1 & 1 & 0 & 1 & 1 & 0 \\
\hline 61 & 0 & 0 & 0 & 1 & 0 & 1 & 1 & 1 & 0 & 1 & 1 & 0 \\
\hline 62 & 0 & 0 & 1 & 1 & 0 & 1 & 1 & 1 & 0 & 1 & 1 & 0 \\
\hline 63 & 0 & 0 & 1 & 1 & 0 & 1 & 1 & 1 & 0 & 0 & 1 & 0 \\
\hline 64 & 0 & 0 & 1 & 0 & 0 & 1 & 1 & 1 & 0 & 1 & 1 & 0 \\
\hline 65 & 0 & 0 & 1 & 1 & 0 & 1 & 1 & 1 & 0 & 1 & 1 & 0 \\
\hline 66 & 0 & 0 & 0 & 1 & 0 & 1 & 1 & 1 & 0 & 1 & 1 & 0 \\
\hline 67 & 0 & 0 & 1 & 0 & 0 & 0 & 1 & 1 & 0 & 1 & 1 & 0 \\
\hline 68 & 0 & 0 & 1 & 1 & 0 & 0 & 1 & 1 & 0 & 1 & 1 & 0 \\
\hline 69 & 0 & 0 & 1 & 0 & 0 & 1 & 1 & 0 & 0 & 1 & 1 & 0 \\
\hline 70 & 0 & 0 & 1 & 0 & 0 & 0 & 1 & 1 & 0 & 0 & 1 & 0 \\
\hline
\end{tabular}

APPLIED ECOLOGY AND ENVIRONMENTAL RESEARCH 18(6):8091-8118. http://www.aloki.hu • ISSN 15891623 (Print) • ISSN1785 0037 (Online) DOI: http://dx.doi.org/10.15666/aeer/1806_80918118 


\begin{tabular}{|c|c|c|c|c|c|c|c|c|c|c|c|c|}
\hline 71 & 0 & 0 & 1 & 0 & 0 & 0 & 1 & 1 & 0 & 1 & 1 & 0 \\
\hline 72 & 0 & 0 & 1 & 0 & 0 & 0 & 1 & 1 & 0 & 0 & 1 & 0 \\
\hline 73 & 0 & 0 & 1 & 1 & 0 & 1 & 1 & 1 & 0 & 0 & 1 & 0 \\
\hline 74 & 0 & 0 & 1 & 1 & 0 & 1 & 1 & 0 & 0 & 0 & 1 & 0 \\
\hline 75 & 0 & 0 & 1 & 0 & 0 & 0 & 1 & 1 & 0 & 0 & 0 & 0 \\
\hline 76 & 0 & 0 & 1 & 0 & 0 & 1 & 1 & 1 & 0 & 0 & 0 & 0 \\
\hline 77 & 0 & 0 & 1 & 1 & 0 & 0 & 0 & 1 & 1 & 0 & 0 & 0 \\
\hline 78 & 0 & 0 & 0 & 1 & 0 & 0 & 0 & 1 & 0 & 0 & 0 & 0 \\
\hline 79 & 0 & 0 & 0 & 0 & 0 & 0 & 0 & 0 & 0 & 0 & 0 & 0 \\
\hline 80 & 0 & 0 & 0 & 1 & 0 & 0 & 0 & 1 & 1 & 0 & 0 & 0 \\
\hline 81 & 1 & 1 & 1 & 1 & 0 & 0 & 0 & 1 & 1 & 0 & 0 & 0 \\
\hline 82 & 0 & 0 & 1 & 0 & 0 & 0 & 0 & 1 & 0 & 0 & 1 & 0 \\
\hline 83 & 0 & 0 & 1 & 1 & 0 & 0 & 0 & 1 & 1 & 1 & 1 & 0 \\
\hline 84 & 1 & 1 & 0 & 1 & 0 & 0 & 1 & 1 & 1 & 0 & 1 & 0 \\
\hline 85 & 0 & 0 & 0 & 1 & 0 & 0 & 1 & 0 & 1 & 0 & 0 & 0 \\
\hline 86 & 0 & 0 & 1 & 1 & 0 & 0 & 1 & 0 & 0 & 0 & 0 & 0 \\
\hline 87 & 0 & 0 & 0 & 1 & 0 & 0 & 1 & 1 & 1 & 0 & 0 & 0 \\
\hline 88 & 0 & 0 & 0 & 1 & 0 & 0 & 1 & 1 & 0 & 0 & 0 & 0 \\
\hline 89 & 0 & 0 & 0 & 1 & 0 & 0 & 1 & 1 & 0 & 0 & 0 & 0 \\
\hline 90 & 0 & 0 & 0 & 1 & 0 & 0 & 0 & 1 & 0 & 1 & 0 & 0 \\
\hline 91 & 0 & 0 & 0 & 0 & 0 & 0 & 1 & 1 & 0 & 0 & 0 & 0 \\
\hline 92 & 0 & 0 & 0 & 0 & 0 & 0 & 0 & 0 & 0 & 0 & 0 & 0 \\
\hline 93 & 1 & 0 & 0 & 1 & 0 & 0 & 0 & 1 & 0 & 0 & 1 & 0 \\
\hline 94 & 0 & 0 & 0 & 0 & 0 & 0 & 1 & 1 & 0 & 0 & 1 & 0 \\
\hline 95 & 1 & 0 & 0 & 0 & 0 & 0 & 1 & 0 & 0 & 0 & 1 & 0 \\
\hline 96 & 0 & 0 & 0 & 0 & 0 & 1 & 0 & 1 & 0 & 0 & 1 & 0 \\
\hline 97 & 0 & 0 & 1 & 1 & 0 & 1 & 0 & 1 & 0 & 0 & 1 & 0 \\
\hline 98 & 1 & 0 & 1 & 1 & 0 & 1 & 0 & 1 & 0 & 1 & 1 & 0 \\
\hline 99 & 0 & 0 & 0 & 1 & 0 & 1 & 0 & 1 & 0 & 1 & 1 & 0 \\
\hline 100 & 0 & 0 & 0 & 1 & 0 & 1 & 0 & 1 & 0 & 1 & 1 & 0 \\
\hline $\begin{array}{l}\text { Acc. } \\
\text { No. }\end{array}$ & $\begin{array}{c}\text { Barc 86 } \\
\text { 200bp } \\
\end{array}$ & $\begin{array}{c}\text { Barc } 86 \\
210 b p \\
\end{array}$ & $\begin{array}{c}\text { WMC773 } \\
298 b p\end{array}$ & $\begin{array}{c}\text { BARC114 } \\
\text { 105bp }\end{array}$ & $\begin{array}{c}\text { BARC } 114 \\
200 b p\end{array}$ & $\begin{array}{c}\text { CSLV } 34 \\
215 b p \\
\end{array}$ & $\begin{array}{c}\text { CSLV 34 } \\
\text { 190bp } \\
\end{array}$ & $\begin{array}{c}\text { CSLV 34 } \\
\text { 150bp } \\
\end{array}$ & $\begin{array}{c}\text { PSP 3000 } \\
\text { 350bp }\end{array}$ & $\begin{array}{c}\text { PSP 3000 } \\
\text { 300bp } \\
\end{array}$ & \begin{tabular}{|c} 
XGWM493 \\
150bp
\end{tabular} & \begin{tabular}{|c} 
XGWM 493 \\
300bp
\end{tabular} \\
\hline 1 & 1 & 0 & 0 & 1 & 0 & 1 & 0 & 0 & 0 & 0 & 0 & 0 \\
\hline 2 & 1 & 0 & 1 & 1 & 0 & 1 & 0 & 0 & 1 & 0 & 0 & 0 \\
\hline 3 & 1 & 0 & 1 & 1 & 0 & 1 & 0 & 0 & 1 & 0 & 0 & 0 \\
\hline 4 & 1 & 0 & 1 & 1 & 0 & 1 & 0 & 0 & 1 & 0 & 0 & 0 \\
\hline 5 & 1 & 0 & 1 & 1 & 0 & 1 & 0 & 0 & 1 & 0 & 0 & 0 \\
\hline
\end{tabular}

APPLIED ECOLOGY AND ENVIRONMENTAL RESEARCH 18(6):8091-8118.

http://www.aloki.hu • ISSN 15891623 (Print) • ISSN1785 0037 (Online)

DOI: http://dx.doi.org/10.15666/aeer/1806_80918118

(๑) 2020, ALÖKI Kft., Budapest, Hungary 
Khattak et al.: Investigating the allelic variation of loci controlling rust resistance genes in wheat (Triticum aestivum L.) land races by SSR marker -8113 -

\begin{tabular}{|c|c|c|c|c|c|c|c|c|c|c|c|c|}
\hline 6 & 1 & 0 & 1 & 1 & 0 & 0 & 1 & 0 & 0 & 0 & 0 & 1 \\
\hline 7 & 1 & 0 & 1 & 1 & 0 & 1 & 0 & 0 & 1 & 0 & 0 & 1 \\
\hline 8 & 1 & 0 & 1 & 1 & 0 & 1 & 0 & 0 & 0 & 0 & 1 & 0 \\
\hline 9 & 1 & 0 & 1 & 1 & 0 & 1 & 0 & 0 & 0 & 0 & 0 & 0 \\
\hline 10 & 0 & 0 & 0 & 1 & 0 & 1 & 0 & 0 & 1 & 0 & 0 & 1 \\
\hline 11 & 1 & 0 & 1 & 1 & 0 & 0 & 0 & 0 & 0 & 0 & 0 & 1 \\
\hline 12 & 0 & 0 & 1 & 1 & 0 & 0 & 0 & 0 & 1 & 1 & 0 & 1 \\
\hline 13 & 1 & 0 & 1 & 1 & 0 & 0 & 0 & 0 & 0 & 0 & 0 & 1 \\
\hline 14 & 1 & 0 & 1 & 1 & 0 & 0 & 1 & 0 & 1 & 0 & 0 & 1 \\
\hline 15 & 1 & 0 & 1 & 1 & 0 & 1 & 0 & 0 & 0 & 0 & 0 & 1 \\
\hline 16 & 1 & 0 & 1 & 1 & 0 & 1 & 0 & 0 & 0 & 1 & 1 & 0 \\
\hline 17 & 1 & 0 & 1 & 1 & 0 & 1 & 0 & 0 & 1 & 0 & 0 & 1 \\
\hline 18 & 1 & 0 & 1 & 1 & 0 & 1 & 0 & 0 & 0 & 1 & 0 & 1 \\
\hline 19 & 0 & 0 & 1 & 1 & 0 & 0 & 0 & 0 & 1 & 0 & 0 & 1 \\
\hline 20 & 1 & 0 & 1 & 0 & 0 & 1 & 0 & 0 & 0 & 0 & 1 & 1 \\
\hline 21 & 1 & 0 & 1 & 0 & 0 & 1 & 0 & 0 & 0 & 1 & 1 & 1 \\
\hline 22 & 1 & 0 & 1 & 1 & 0 & 1 & 0 & 0 & 0 & 0 & 1 & 1 \\
\hline 23 & 0 & 0 & 1 & 1 & 0 & 1 & 0 & 0 & 0 & 0 & 1 & 1 \\
\hline 24 & 1 & 0 & 1 & 1 & 0 & 0 & 0 & 0 & 1 & 1 & 1 & 1 \\
\hline 25 & 1 & 0 & 1 & 1 & 0 & 0 & 1 & 0 & 1 & 1 & 1 & 1 \\
\hline 26 & 1 & 0 & 1 & 0 & 0 & 1 & 0 & 0 & 0 & 0 & 1 & 1 \\
\hline 27 & 1 & 0 & 1 & 1 & 0 & 0 & 1 & 0 & 0 & 0 & 1 & 1 \\
\hline 28 & 1 & 0 & 1 & 0 & 0 & 0 & 1 & 0 & 0 & 0 & 1 & 1 \\
\hline 29 & 1 & 0 & 1 & 1 & 1 & 0 & 1 & 0 & 0 & 0 & 1 & 1 \\
\hline 30 & 1 & 0 & 1 & 1 & 0 & 0 & 1 & 0 & 0 & 1 & 1 & 1 \\
\hline 31 & 1 & 0 & 1 & 1 & 1 & 1 & 0 & 0 & 0 & 0 & 1 & 1 \\
\hline 32 & 1 & 0 & 1 & 1 & 1 & 0 & 1 & 0 & 0 & 0 & 1 & 1 \\
\hline 33 & 1 & 0 & 1 & 1 & 0 & 0 & 1 & 0 & 1 & 1 & 1 & 1 \\
\hline 34 & 1 & 0 & 1 & 1 & 0 & 0 & 0 & 0 & 0 & 0 & 1 & 1 \\
\hline 35 & 1 & 0 & 1 & 1 & 0 & 0 & 0 & 0 & 1 & 1 & 1 & 1 \\
\hline 36 & 1 & 0 & 1 & 1 & 0 & 0 & 0 & 0 & 1 & 1 & 1 & 1 \\
\hline 37 & 1 & 0 & 1 & 1 & 0 & 0 & 1 & 0 & 0 & 0 & 1 & 1 \\
\hline 38 & 1 & 0 & 1 & 1 & 0 & 0 & 1 & 1 & 0 & 0 & 1 & 1 \\
\hline 39 & 0 & 0 & 1 & 1 & 0 & 1 & 0 & 0 & 1 & 1 & 0 & 0 \\
\hline 40 & 1 & 0 & 1 & 1 & 0 & 1 & 0 & 0 & 0 & 0 & 1 & 1 \\
\hline 41 & 1 & 0 & 1 & 1 & 0 & 0 & 1 & 0 & 0 & 0 & 0 & 1 \\
\hline 42 & 1 & 0 & 1 & 1 & 0 & 1 & 0 & 0 & 1 & 1 & 1 & 1 \\
\hline
\end{tabular}

APPLIED ECOLOGY AND ENVIRONMENTAL RESEARCH 18(6):8091-8118. http://www.aloki.hu • ISSN 15891623 (Print) • ISSN1785 0037 (Online) DOI: http://dx.doi.org/10.15666/aeer/1806_80918118 
Khattak et al.: Investigating the allelic variation of loci controlling rust resistance genes in wheat (Triticum aestivum L.) land races by SSR marker -8114 -

\begin{tabular}{|c|c|c|c|c|c|c|c|c|c|c|c|c|}
\hline 43 & 1 & 0 & 1 & 1 & 0 & 1 & 0 & 0 & 0 & 0 & 1 & 1 \\
\hline 44 & 1 & 0 & 1 & 1 & 0 & 1 & 0 & 0 & 0 & 0 & 1 & 1 \\
\hline 45 & 1 & 0 & 1 & 1 & 0 & 1 & 0 & 0 & 0 & 0 & 1 & 1 \\
\hline 46 & 1 & 0 & 1 & 1 & 0 & 1 & 0 & 0 & 0 & 1 & 1 & 1 \\
\hline 47 & 1 & 0 & 1 & 1 & 0 & 1 & 0 & 0 & 0 & 0 & 1 & 1 \\
\hline 48 & 1 & 0 & 1 & 1 & 0 & 1 & 0 & 0 & 0 & 0 & 1 & 1 \\
\hline 49 & 1 & 0 & 1 & 1 & 0 & 1 & 0 & 0 & 0 & 0 & 1 & 1 \\
\hline 50 & 1 & 0 & 1 & 1 & 0 & 1 & 0 & 0 & 0 & 0 & 1 & 1 \\
\hline 51 & 1 & 0 & 1 & 1 & 0 & 1 & 0 & 0 & 0 & 0 & 1 & 1 \\
\hline 52 & 1 & 0 & 1 & 1 & 0 & 1 & 0 & 0 & 0 & 0 & 1 & 1 \\
\hline 53 & 1 & 0 & 1 & 1 & 0 & 1 & 0 & 0 & 0 & 0 & 1 & 1 \\
\hline 54 & 1 & 0 & 1 & 1 & 0 & 0 & 0 & 0 & 0 & 0 & 1 & 1 \\
\hline 55 & 1 & 0 & 1 & 1 & 0 & 1 & 0 & 0 & 0 & 0 & 1 & 1 \\
\hline 56 & 1 & 0 & 1 & 1 & 0 & 1 & 0 & 0 & 0 & 0 & 1 & 1 \\
\hline 57 & 1 & 0 & 1 & 1 & 0 & 1 & 0 & 0 & 0 & 0 & 1 & 1 \\
\hline 58 & 0 & 0 & 0 & 1 & 0 & 1 & 0 & 0 & 0 & 0 & 1 & 0 \\
\hline 59 & 1 & 0 & 0 & 1 & 0 & 1 & 0 & 0 & 0 & 0 & 1 & 0 \\
\hline 60 & 1 & 0 & 0 & 1 & 0 & 1 & 0 & 0 & 0 & 0 & 1 & 0 \\
\hline 61 & 1 & 0 & 0 & 1 & 0 & 0 & 1 & 0 & 0 & 0 & 1 & 0 \\
\hline 62 & 1 & 0 & 0 & 1 & 0 & 0 & 0 & 0 & 0 & 0 & 1 & 0 \\
\hline 63 & 1 & 0 & 0 & 1 & 0 & 1 & 0 & 0 & 0 & 0 & 1 & 0 \\
\hline 64 & 1 & 0 & 0 & 1 & 0 & 0 & 0 & 0 & 0 & 0 & 1 & 0 \\
\hline 65 & 1 & 0 & 0 & 1 & 0 & 0 & 0 & 1 & 0 & 1 & 1 & 0 \\
\hline 66 & 1 & 0 & 0 & 1 & 0 & 1 & 0 & 0 & 0 & 0 & 1 & 0 \\
\hline 67 & 1 & 0 & 0 & 1 & 0 & 1 & 0 & 0 & 0 & 0 & 1 & 0 \\
\hline 68 & 1 & 0 & 0 & 1 & 0 & 1 & 0 & 0 & 0 & 1 & 1 & 0 \\
\hline 69 & 1 & 0 & 0 & 1 & 0 & 1 & 0 & 0 & 0 & 0 & 1 & 0 \\
\hline 70 & 1 & 0 & 0 & 1 & 0 & 1 & 0 & 0 & 0 & 0 & 1 & 0 \\
\hline 71 & 1 & 0 & 0 & 1 & 0 & 0 & 0 & 0 & 0 & 0 & 1 & 0 \\
\hline 72 & 1 & 0 & 0 & 1 & 0 & 0 & 0 & 0 & 0 & 0 & 1 & 0 \\
\hline 73 & 1 & 0 & 0 & 1 & 0 & 0 & 0 & 0 & 0 & 0 & 1 & 0 \\
\hline 74 & 1 & 0 & 0 & 1 & 0 & 0 & 0 & 0 & 0 & 0 & 1 & 0 \\
\hline 75 & 1 & 0 & 0 & 1 & 0 & 0 & 0 & 0 & 0 & 0 & 1 & 0 \\
\hline 76 & 1 & 0 & 0 & 1 & 0 & 0 & 0 & 0 & 0 & 0 & 1 & 0 \\
\hline 77 & 1 & 0 & 1 & 1 & 0 & 0 & 0 & 0 & 0 & 0 & 0 & 1 \\
\hline 78 & 1 & 1 & 1 & 1 & 0 & 0 & 0 & 0 & 0 & 0 & 0 & 1 \\
\hline 79 & 1 & 0 & 1 & 1 & 0 & 0 & 0 & 0 & 0 & 1 & 0 & 1 \\
\hline
\end{tabular}

APPLIED ECOLOGY AND ENVIRONMENTAL RESEARCH 18(6):8091-8118. http://www.aloki.hu • ISSN 15891623 (Print) • ISSN1785 0037 (Online) DOI: http://dx.doi.org/10.15666/aeer/1806_80918118 


\begin{tabular}{|c|c|c|c|c|c|c|c|c|c|c|c|c|}
\hline 80 & 1 & 0 & 1 & 1 & 0 & 0 & 0 & 0 & 0 & 0 & 0 & 1 \\
\hline 81 & 1 & 1 & 0 & 1 & 0 & 0 & 0 & 0 & 0 & 0 & 0 & 1 \\
\hline 82 & 1 & 1 & 1 & 0 & 0 & 0 & 0 & 0 & 0 & 0 & 0 & 1 \\
\hline 83 & 1 & 1 & 1 & 1 & 0 & 0 & 0 & 0 & 1 & 1 & 0 & 1 \\
\hline 84 & 1 & 0 & 1 & 1 & 0 & 0 & 0 & 0 & 0 & 0 & 0 & 1 \\
\hline 85 & 1 & 1 & 1 & 1 & 0 & 1 & 0 & 0 & 1 & 1 & 0 & 1 \\
\hline 86 & 1 & 0 & 0 & 0 & 0 & 0 & 0 & 0 & 1 & 1 & 0 & 0 \\
\hline 87 & 1 & 1 & 1 & 0 & 0 & 0 & 0 & 0 & 0 & 0 & 0 & 1 \\
\hline 88 & 1 & 0 & 1 & 0 & 0 & 0 & 0 & 0 & 0 & 0 & 0 & 1 \\
\hline 89 & 1 & 1 & 1 & 0 & 0 & 0 & 0 & 0 & 1 & 0 & 0 & 1 \\
\hline 90 & 1 & 1 & 1 & 0 & 0 & 0 & 0 & 0 & 1 & 1 & 0 & 1 \\
\hline 91 & 1 & 0 & 0 & 0 & 0 & 0 & 0 & 0 & 0 & 0 & 0 & 0 \\
\hline 92 & 1 & 0 & 0 & 0 & 0 & 1 & 0 & 0 & 0 & 0 & 0 & 0 \\
\hline 93 & 1 & 0 & 0 & 0 & 0 & 1 & 0 & 0 & 0 & 0 & 0 & 0 \\
\hline 94 & 1 & 0 & 1 & 0 & 0 & 0 & 1 & 0 & 0 & 0 & 0 & 0 \\
\hline 95 & 1 & 0 & 1 & 1 & 0 & 0 & 0 & & 0 & 1 & 0 & 0 \\
\hline 96 & 1 & 0 & 1 & 0 & 0 & 1 & 0 & 0 & 0 & 0 & 0 & 1 \\
\hline 97 & 1 & 0 & 1 & 1 & 0 & 1 & 0 & 0 & 0 & 0 & 0 & 1 \\
\hline 98 & 1 & 0 & 1 & 1 & 0 & 1 & 0 & 0 & 0 & 0 & 0 & 1 \\
\hline 99 & 1 & 0 & 1 & 1 & 0 & 1 & 0 & 0 & 0 & 0 & 0 & 1 \\
\hline 100 & 1 & 0 & 1 & 1 & 0 & 1 & 0 & 0 & 0 & 0 & 0 & 1 \\
\hline $\begin{array}{l}\text { Acc } \\
\text { No. }\end{array}$ & $\begin{array}{c}\text { XGWM } \\
153 \\
100 \mathrm{bp} \\
\end{array}$ & $\begin{array}{c}\text { XGWM } \\
153300 \text { bp }\end{array}$ & $\begin{array}{c}\text { XGWM } \\
111 \text { 185bp }\end{array}$ & $\begin{array}{c}\text { XGWM } 44 \\
120 b p\end{array}$ & $\begin{array}{c}\text { XGWM } \\
44 \\
285 \mathrm{bp} \\
\end{array}$ & $\begin{array}{c}\text { XGWM44 } \\
\text { 500bp }\end{array}$ & $\begin{array}{c}\text { XGWM44 } \\
\text { 700bp }\end{array}$ & $\begin{array}{c}\text { XBARC4 } \\
\text { 90bp }\end{array}$ & $\begin{array}{c}\text { XBARC4 } \\
\text { 200bp }\end{array}$ & $\begin{array}{c}\text { XGDM } \\
125 \\
150 \mathrm{bp} \\
\end{array}$ & $\begin{array}{c}\text { XGDM } \\
125 \\
190 \mathrm{bp} \\
\end{array}$ & $\begin{array}{c}\text { XGWM } \\
410 \\
140 \mathrm{bp} \\
\end{array}$ \\
\hline 1 & 1 & 1 & 1 & 1 & 1 & 1 & 0 & 1 & 0 & 0 & 1 & 1 \\
\hline 2 & 1 & 1 & 0 & 1 & 1 & 1 & 0 & 1 & 0 & 0 & 1 & 1 \\
\hline 3 & 1 & 0 & 1 & 0 & 0 & 0 & 1 & 1 & 0 & 0 & 1 & 0 \\
\hline 4 & 1 & 0 & 1 & 1 & 1 & 0 & 0 & 1 & 0 & 0 & 1 & 0 \\
\hline 5 & 1 & 0 & 1 & 0 & 0 & 0 & 1 & 1 & 0 & 0 & 1 & 1 \\
\hline 6 & 1 & 0 & 1 & 1 & 1 & 0 & 0 & 1 & 0 & 0 & 1 & 1 \\
\hline 7 & 1 & 0 & 1 & 1 & 1 & 0 & 0 & 1 & 0 & 0 & 1 & 1 \\
\hline 8 & 1 & 0 & 1 & 1 & 1 & 0 & 0 & 0 & 0 & 0 & 1 & 0 \\
\hline 9 & 1 & 0 & 1 & 1 & 1 & 0 & 0 & 1 & 0 & 0 & 0 & 1 \\
\hline 10 & 1 & 0 & 1 & 1 & 1 & 0 & 0 & 0 & 0 & 0 & 0 & 1 \\
\hline 11 & 1 & 0 & 1 & 1 & 1 & 1 & 0 & 0 & 0 & 0 & 0 & 1 \\
\hline 12 & 1 & 0 & 1 & 1 & 1 & 1 & 1 & 0 & 0 & 0 & 0 & 1 \\
\hline 13 & 0 & 0 & 1 & 0 & 0 & 1 & 1 & 1 & 0 & 0 & 1 & 1 \\
\hline
\end{tabular}

APPLIED ECOLOGY AND ENVIRONMENTAL RESEARCH 18(6):8091-8118.

http://www.aloki.hu • ISSN 15891623 (Print) • ISSN1785 0037 (Online)

DOI: http://dx.doi.org/10.15666/aeer/1806_80918118

(c) 2020, ALÖKI Kft., Budapest, Hungary 
Khattak et al.: Investigating the allelic variation of loci controlling rust resistance genes in wheat (Triticum aestivum L.) land races by SSR marker -8116 -

\begin{tabular}{|c|c|c|c|c|c|c|c|c|c|c|c|c|}
\hline 14 & 1 & 0 & 1 & 1 & 1 & 0 & 0 & 1 & 0 & 0 & 1 & 1 \\
\hline 15 & 1 & 0 & 0 & 1 & 1 & 1 & 0 & 1 & 0 & 0 & 1 & 0 \\
\hline 16 & 1 & 0 & 1 & 1 & 1 & 0 & 0 & 0 & 0 & 0 & 1 & 1 \\
\hline 17 & 0 & 0 & 1 & 0 & 0 & 0 & 0 & 1 & 0 & 0 & 0 & 0 \\
\hline 18 & 0 & 0 & 0 & 0 & 0 & 0 & 0 & 0 & 0 & 0 & 1 & 0 \\
\hline 19 & 1 & 0 & 1 & 1 & 1 & 0 & 0 & 1 & 0 & 1 & 0 & 0 \\
\hline 20 & 0 & 0 & 1 & 1 & 1 & 0 & 0 & 1 & 0 & 1 & 0 & 0 \\
\hline 21 & 1 & 0 & 1 & 1 & 1 & 0 & 0 & 1 & 0 & 0 & 0 & 0 \\
\hline 22 & 1 & 0 & 1 & 1 & 1 & 0 & 0 & 1 & 1 & 1 & 0 & 0 \\
\hline 23 & 1 & 0 & 1 & 1 & 1 & 0 & 0 & 0 & 1 & 1 & 0 & 0 \\
\hline 24 & 1 & 0 & 1 & 1 & 1 & 0 & 0 & 1 & 1 & 1 & 0 & 1 \\
\hline 25 & 1 & 0 & 1 & 1 & 1 & 0 & 0 & 1 & 1 & 0 & 0 & 1 \\
\hline 26 & 1 & 0 & 1 & 1 & 1 & 0 & 0 & 1 & 0 & 1 & 0 & 1 \\
\hline 27 & 1 & 0 & 1 & 1 & 1 & 0 & 0 & 1 & 1 & 0 & 0 & 1 \\
\hline 28 & 1 & 0 & 1 & 1 & 1 & 0 & 0 & 1 & 0 & 1 & 0 & 0 \\
\hline 29 & 0 & 0 & 1 & 1 & 1 & 0 & 0 & 1 & 1 & 1 & 0 & 1 \\
\hline 30 & 1 & 0 & 1 & 1 & 1 & 0 & 0 & 1 & 0 & 1 & 0 & 1 \\
\hline 31 & 0 & 0 & 1 & 1 & 1 & 0 & 0 & 1 & 0 & 1 & 0 & 1 \\
\hline 32 & 1 & 0 & 0 & 1 & 1 & 0 & 0 & 1 & 0 & 1 & 0 & 1 \\
\hline 33 & 0 & 0 & 0 & 1 & 1 & 0 & 0 & 1 & 0 & 1 & 0 & 1 \\
\hline 34 & 1 & 0 & 1 & 1 & 1 & 0 & 0 & 1 & 0 & 1 & 0 & 0 \\
\hline 35 & 1 & 0 & 1 & 1 & 1 & 0 & 0 & 1 & 0 & 1 & 0 & 1 \\
\hline 36 & 1 & 0 & 0 & 1 & 1 & 0 & 0 & 1 & 0 & 1 & 0 & 1 \\
\hline 37 & 0 & 0 & 0 & 0 & 0 & 0 & 0 & 1 & 0 & 1 & 0 & 1 \\
\hline 38 & 0 & 0 & 1 & 0 & 1 & 0 & 0 & 1 & 0 & 1 & 0 & 1 \\
\hline 39 & 1 & 0 & 1 & 0 & 1 & 0 & 0 & 0 & 0 & 0 & 0 & 1 \\
\hline 40 & 1 & 0 & 1 & 0 & 0 & 0 & 0 & 1 & 0 & 1 & 0 & 0 \\
\hline 41 & 1 & 0 & 1 & 0 & 1 & 0 & 0 & 1 & 0 & 0 & 0 & 0 \\
\hline 42 & 1 & 0 & 1 & 0 & 1 & 0 & 0 & 1 & 0 & 1 & 0 & 1 \\
\hline 43 & 1 & 0 & 1 & 0 & 0 & 0 & 0 & 1 & 0 & 1 & 0 & 1 \\
\hline 44 & 1 & 0 & 1 & 0 & 0 & 0 & 0 & 1 & 0 & 1 & 0 & 0 \\
\hline 45 & 1 & 0 & 1 & 0 & 0 & 0 & 0 & 1 & 0 & 0 & 0 & 0 \\
\hline 46 & 1 & 0 & 0 & 0 & 0 & 0 & 0 & 1 & 0 & 0 & 0 & 0 \\
\hline 47 & 1 & 0 & 0 & 0 & 1 & 0 & 0 & 1 & 0 & 1 & 0 & 0 \\
\hline 48 & 1 & 0 & 0 & 0 & 1 & 0 & 0 & 1 & 0 & 0 & 0 & 0 \\
\hline 49 & 1 & 0 & 0 & 0 & 1 & 0 & 0 & 1 & 0 & 1 & 0 & 0 \\
\hline 50 & 1 & 0 & 1 & 0 & 1 & 0 & 0 & 1 & 0 & 0 & 0 & 0 \\
\hline
\end{tabular}

APPLIED ECOLOGY AND ENVIRONMENTAL RESEARCH 18(6):8091-8118.

http://www.aloki.hu • ISSN 15891623 (Print) • ISSN1785 0037 (Online)

DOI: http://dx.doi.org/10.15666/aeer/1806_80918118

(๖) 2020, ALÖKI Kft., Budapest, Hungary 
Khattak et al.: Investigating the allelic variation of loci controlling rust resistance genes in wheat (Triticum aestivum L.) land races by SSR marker -8117 -

\begin{tabular}{|c|c|c|c|c|c|c|c|c|c|c|c|c|}
\hline 51 & 1 & 0 & 1 & 0 & 1 & 0 & 0 & 1 & 1 & 1 & 0 & 1 \\
\hline 52 & 1 & 0 & 1 & 0 & 1 & 0 & 0 & 1 & 0 & 1 & 0 & 0 \\
\hline 53 & 1 & 0 & 1 & 0 & 0 & 0 & 0 & 1 & 0 & 0 & 0 & 1 \\
\hline 54 & 1 & 0 & 1 & 0 & 0 & 0 & 0 & 1 & 0 & 1 & 0 & 1 \\
\hline 55 & 1 & 0 & 0 & 0 & 0 & 0 & 0 & 0 & 1 & 0 & 0 & 0 \\
\hline 56 & 1 & 0 & 1 & 0 & 1 & 0 & 0 & 0 & 1 & 0 & 0 & 1 \\
\hline 57 & 1 & 0 & 0 & 0 & 1 & 0 & 0 & 0 & 1 & 1 & 0 & 1 \\
\hline 58 & 1 & 0 & 0 & 0 & 0 & 0 & 0 & 0 & 1 & 1 & 0 & 1 \\
\hline 59 & 1 & 0 & 0 & 0 & 1 & 0 & 0 & 0 & 1 & 0 & 0 & 1 \\
\hline 60 & 1 & 0 & 0 & 0 & 1 & 0 & 0 & 0 & 1 & 0 & 0 & 1 \\
\hline 61 & 1 & 0 & 0 & 0 & 1 & 0 & 0 & 0 & 1 & 1 & 0 & 0 \\
\hline 62 & 0 & 0 & 0 & 0 & 1 & 0 & 0 & 0 & 1 & 0 & 0 & 0 \\
\hline 63 & 0 & 0 & 0 & 0 & 1 & 0 & 0 & 0 & 1 & 1 & 0 & 1 \\
\hline 64 & 1 & 0 & 1 & 0 & 1 & 0 & 0 & 0 & 1 & 1 & 0 & 1 \\
\hline 65 & 0 & 0 & 0 & 0 & 0 & 0 & 0 & 0 & 1 & 1 & 0 & 0 \\
\hline 66 & 1 & 0 & 1 & 0 & 1 & 0 & 0 & 0 & 1 & 0 & 0 & 1 \\
\hline 67 & 1 & 0 & 0 & 0 & 1 & 0 & 0 & 0 & 1 & 1 & 0 & 1 \\
\hline 68 & 1 & 0 & 1 & 0 & 1 & 0 & 1 & 0 & 1 & 0 & 0 & 1 \\
\hline 69 & 1 & 0 & 1 & 0 & 1 & 1 & 0 & 0 & 1 & 1 & 0 & 1 \\
\hline 70 & 0 & 0 & 1 & 0 & 0 & 0 & 1 & 0 & 0 & 1 & 0 & 1 \\
\hline 71 & 0 & 0 & 1 & 0 & 0 & 0 & 1 & 0 & 1 & 0 & 0 & 1 \\
\hline 72 & 1 & 0 & 0 & 1 & 1 & 0 & 0 & 1 & 1 & 1 & 0 & 0 \\
\hline 73 & 1 & 0 & 0 & 1 & 1 & 0 & 0 & 1 & 1 & 1 & 0 & 1 \\
\hline 74 & 1 & 0 & 1 & 0 & 1 & 0 & 0 & 1 & 1 & 0 & 0 & 1 \\
\hline 75 & 1 & 0 & 1 & 0 & 0 & 0 & 0 & 1 & 1 & 1 & 0 & 0 \\
\hline 76 & 1 & 0 & 1 & 0 & 0 & 0 & 0 & 1 & 1 & 0 & 0 & 0 \\
\hline 77 & 1 & 0 & 1 & 0 & 1 & 0 & 0 & 0 & 1 & 0 & 0 & 0 \\
\hline 78 & 1 & 0 & 1 & 0 & 0 & 0 & 0 & 1 & 1 & 0 & 0 & 0 \\
\hline 79 & 1 & 0 & 1 & 0 & 0 & 0 & 0 & 1 & 1 & 0 & 0 & 0 \\
\hline 80 & 1 & 0 & 1 & 0 & 1 & 0 & 0 & 1 & 1 & 0 & 0 & 0 \\
\hline 81 & 1 & 0 & 1 & 0 & 1 & 0 & 0 & 1 & 1 & 0 & 0 & 0 \\
\hline 82 & 1 & 0 & 1 & 0 & 1 & 0 & 0 & 1 & 1 & 0 & 0 & 1 \\
\hline 83 & 1 & 0 & 0 & 0 & 0 & 0 & 0 & 1 & 1 & 0 & 0 & 1 \\
\hline 84 & 1 & 0 & 1 & 0 & 1 & 0 & 0 & 1 & 1 & 0 & 0 & 1 \\
\hline 85 & 0 & 0 & 0 & 0 & 1 & 0 & 0 & 0 & 0 & 0 & 0 & 0 \\
\hline 86 & 1 & 0 & 1 & 0 & 1 & 0 & 0 & 0 & 0 & 0 & 0 & 0 \\
\hline 87 & 1 & 0 & 1 & 0 & 1 & 0 & 0 & 0 & 0 & 0 & 0 & 0 \\
\hline
\end{tabular}

APPLIED ECOLOGY AND ENVIRONMENTAL RESEARCH 18(6):8091-8118. http://www.aloki.hu • ISSN 15891623 (Print) • ISSN1785 0037 (Online) DOI: http://dx.doi.org/10.15666/aeer/1806_80918118 
Khattak et al.: Investigating the allelic variation of loci controlling rust resistance genes in wheat (Triticum aestivum $\mathrm{L}$.) land races by SSR marker -8118 -

\begin{tabular}{|c|c|c|c|c|c|c|c|c|c|c|c|c|}
\hline 88 & 1 & 0 & 0 & 0 & 1 & 0 & 0 & 0 & 0 & 0 & 0 & 0 \\
\hline 89 & 1 & 0 & 0 & 0 & 0 & 0 & 0 & 0 & 1 & 0 & 0 & 0 \\
\hline 90 & 0 & 0 & 1 & 0 & 0 & 0 & 0 & 0 & 1 & 0 & 0 & 0 \\
\hline 91 & 1 & 0 & 0 & 0 & 0 & 0 & 0 & 0 & 1 & 0 & 0 & 0 \\
\hline 92 & 1 & 0 & 0 & 0 & 1 & 0 & 0 & 0 & 1 & 0 & 0 & 0 \\
\hline 93 & 0 & 0 & 0 & 0 & 1 & 0 & 0 & 0 & 1 & 0 & 0 & 1 \\
\hline 94 & 0 & 0 & 1 & 0 & 1 & 0 & 0 & 0 & 1 & 0 & 0 & 1 \\
\hline 95 & 1 & 0 & 1 & 0 & 1 & 0 & 0 & 0 & 1 & 0 & 0 & 1 \\
\hline 96 & 1 & 0 & 1 & 0 & 1 & 0 & 0 & 0 & 1 & 1 & 0 & 1 \\
\hline 97 & 1 & 0 & 1 & 0 & 1 & 0 & 0 & 0 & 1 & 1 & 0 & 1 \\
\hline 98 & 1 & 0 & 1 & 0 & 1 & 0 & 0 & 0 & 1 & 1 & 0 & 1 \\
\hline 99 & 1 & 0 & 1 & 0 & 1 & 0 & 0 & 0 & 1 & 0 & 0 & 0 \\
\hline 100 & 1 & 0 & 1 & 0 & 1 & 0 & 0 & 0 & 1 & 1 & 0 & 1 \\
\hline
\end{tabular}

APPLIED ECOLOGY AND ENVIRONMENTAL RESEARCH 18(6):8091-8118.

http://www.aloki.hu • ISSN 15891623 (Print) • ISSN1785 0037 (Online)

DOI: http://dx.doi.org/10.15666/aeer/1806_80918118

(c) 2020, ALÖKI Kft., Budapest, Hungary 